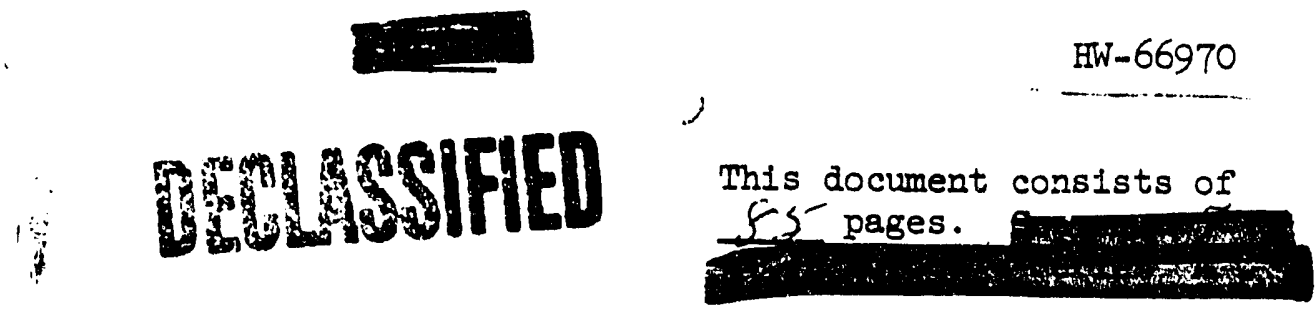

$\frac{\text { IRRADIATION PROCESSING DEPARTMENT }}{\text { SENTILY REPORT }}$

$\mathrm{HW}--66970$

DE93 001252

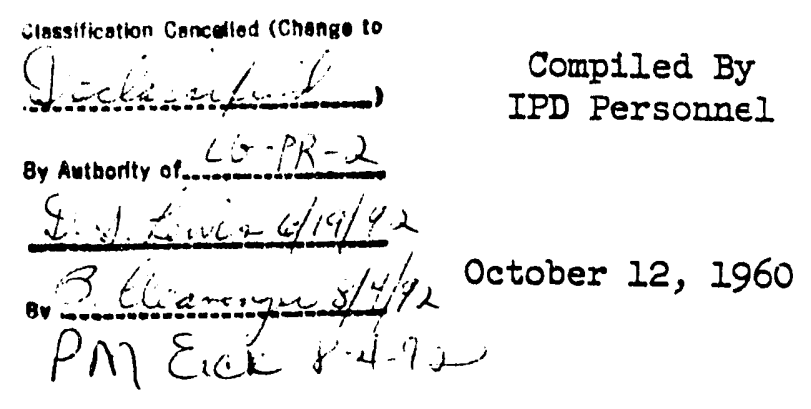

RICHLAND, WASHINGTON

Work performed under Contract No. AT (45-1)-1350 between the Atomic Dergy Commission and the General Electric Company.

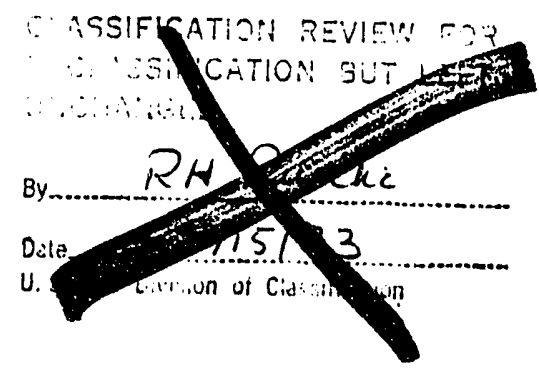

This document condins Recture Data as defined in the Atomic Energy Act of 1954 and contents in any nauthorized person is prohibited.

\begin{tabular}{|c|c|c|c|c|}
\hline Route To: & E.R. No. & Location & $\begin{array}{l}\text { F1les } \\
\text { Route Date } \\
\end{array}$ & $\begin{array}{l}\text { S1gnature } \\
\text { and Date }\end{array}$ \\
\hline $4 x$ & & & & \\
\hline lille & ere & & & \\
\hline & & & & \\
\hline
\end{tabular}

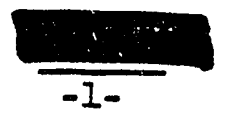




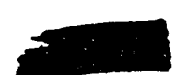

DISTRIBUTION

\section{Copy Number}

1

2

3

4

$5-6-7-8$

$9-10$

11

12

13

14

15

16

17

18

19

20
W. E. Johnson

A. B. Greninger

H. M. Parker

APD, F. E. Crever

AEC-BOO, J. E. Travis

AEC Production Division, G. F. Quinn

AEC-SROO, R. C. Blair

R. I. Dickeman

O. H. Greager

R. T. Jessen

O. C. Schroeder

W. A. Shanks

J. S. MaMahon

S. H. Small

300 Area File

Records Center

\section{DISCLAIMER}

This report was prepared as an account of work sponsored by an agency of the United States Government. Neither the United States Government nor any agency thereof, nor any of their employees, makes any warranty, express or implied, or assumes any legal liability or responsibility for the accuracy, completeness, or usefulness of any information, apparatus, product, or process disclosed, or represents that its use would not infringe privately owned rights. Reference herein to any specific commercial product, process, or service by trade name, trademark, manufacturer, or otherwise does not necessarily constitute or imply its endorsement, recommendation, or favoring by the United States Government or any agency thereof. The views and opinions of authors expressed herein do not necessarily state or reflect those of the United States Government or any agency thereof.

\section{DEUASSFFED}

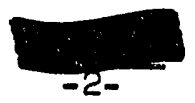


STMMARY

GENIERAL

RESEARCH \& ENGINGERING OPERATION

Process and Reactor Development Operation B-I

Process Technology Operation

$\mathrm{B}-1$
$\mathrm{~B}-10$

Operational Physics Operation

$\mathrm{B}-10$

Testing Operation

MANUFACTURING OPERATION

Production Operation

Reactor Operation Statistics

C-1

Applied Reactor Bngineering Operation

C-2

B-C Reactor Operation

C-7

D-.DR Reactor Operation

C-12

F Reactor Operation

c-14

H Reactor Operation

c-16

$\mathrm{KE}-\mathrm{KW}$ Reactor Operation

C-18

C-19

FACILITIES ENGINGHERING OPERATION

Reactor Modification Design Operation

D-1

Equipment Development Operation

Plant Englneering Operation

D-3

Project Engineering Operation

D-5

D-7

NPR PROJECT OPERATION

Process Design

Fleidi and Operations Englneering

E-1

Program Evaluation

FINANCIAL OPERATION

Process Design

Field and Operations Fngineering

Program Evaluation

FINANCIAL OPEEATION

F-1

RELATIONS PRACTICES OPERATION

G-1

SIGNIFICANT RBPORTS ISSUED

H-I

TRIPS

H-3

VISITORS 


\section{SUMMARY \\ DECI APSATE \\ RESEARCH \& ENGINEERING OPERATION}

Irradiation of self-supported fuel elements charged in B and C Reactors continued without failure. Twenty columns of bumper elements, ten with four rails and ten with three ralls, were charged into D Reactor to determine handling problems with these designs. Four columns of enriched bumper elements were discharged from $D$ Reactor and showed an improvement factor of 38 with a $95 \%$ confldence level over normal I\& fuel.

The test irradiations in support of NPR fuel development continued in KER Loops 3 and 4 . The heavy-walled single-tube elements and defected fuel elements in KRR-3 have rec. 'ed about $970 \mathrm{MWD} / \mathrm{T}$ of the goal exposure of $2500 \mathrm{MWD} / \mathrm{T}$. The elght natural urantum tube-and-tube elements in KGR- 4 have reached about $1560 \mathrm{MWD} / \mathrm{T}$ of the scheduled $2500 \mathrm{MWD} / \mathrm{T}$ exposure.

The Monte Carlo program was used to compute first-flight collisions of fast neutrons in concentric-cylinder fuel geometries. Results were comparable to the previously used Homogenization Model.

The first $k_{\infty}$ measurement in the PCTR has been completed for the NPR geometry. The measured value was slightly lower than previously calcula,ted.

Chemical analysis and dih purlty values of the flrst shipments of NPR core graphite from National Carbon Company show that the material meets the specification for nuclear purity. Assignment of test reactor space for highflux testing of the material has been requested.

Tests of methods to reduce the concentration of critical isotopes in reactoreffluent water were continued at 100-D and started at 100-II and B. At 107-D the retention of critical isotopes by aluminum turnings has been demonstrated at f..ow rates exceeding the laboratory rate previously used. Substitution of aluminum nitrate for the sulfate in water treatment is being made on a half-reactor basis at 100-H to determine the effect of reducing the phosphorus and sulfur in the influent on the Phosphorus-32 in the effluent. A halfreactor test at 100-B was infilated with the same objective as the H test, but using an increased aluminum sulfate feed rate rather than substituting aluminum nitrate. Also, beglnning this month the reporting of total effluent activity by reactor will be replaced by a report of the concentration of the critical isotopes in the effluent of each reactor.

A new spline coller was Installed and successfully used at D Reactor. The unit permitted full use of the spline system for startup control and resulted in a significant reduction in nonequilibrium losses.

The primary power level limit at $C, K F$ and $K W$ Reactors was based on fuel element fallure control. The other reactors were restricted by bulk outlet
temperature limits.
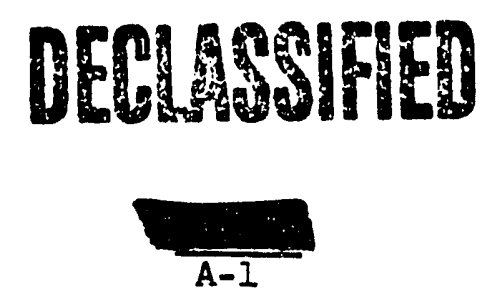
MANUFACTURING OPERATION

Production

Reactor Input production was 8.2 percent above forecast; 0.9 percent above at the six old reactors and 18.4 percent above at the $K^{\prime} s$. Forecast was exceeded due to high time operated efflclency and average power levels, at the K's.

Overall time operated efflclency was 83.0 percent ( 82 percent forecast); 80.2 at the six old reactors and 91.6 at the $\mathrm{K}^{\prime} \mathrm{s}$. A new time operated efficiency record of 94.5 at. $K E$ exceeded theil previous maximum (May, 1960) by 1.2 percent.

There was no increase in the combined reactcr instantaneous power level or the individual reactor record power levels.

Three ruptures, two I\&E regular metal and one I\&E enrlched were removed from the reactors. The regular metal ruptures were at $C$ and $D$, the enriched at DR. The enriched rupture falled at Il percent of goal concentration due to mechanical damage. This represents the best rupture experience since November, 1959 and is 66 percent lower than the prevlous best month's expertence during 1960.

\section{Engineering}

A study to review the progress of development and test work and to firm up plans relative to scope and schedule for the Bumper Fuel Program was summarized in a letter to the Manager, Manufacturing (Document HW-66919, issued September 27, 1960). A target schedule recommended for planning and budgeting purposes assigns general priority to the conversion of $\mathrm{K}$ Reactors following the lead-reactor application at $D$ Reactor and application at $\mathrm{H}$ Reactor for the E-N Load Demonstration. The recomendation, based mainly upon economic considerations, recognizes that contingencles such as fuel avallability and nozzle procurement lead-time may dictate conversion of a third old reactor prior to the $K^{\prime} s$ in preference to delaying the total program.

A study is in progress to find ways of reducing helium losses. It includes review of system components and system operation, recomending improved operation procedures for unloading, addition, and purging, methods of leak detection and subsequent correction. Facilities Engineering has been requested to prepare an engineering scope of a gas purffication and recovery system.

A study has shown that the extensive modifications to 105-C metal loading elevator, as required by code and sound engineering to adapt it to carry personnel, would be more costly than providing a new elevator for the personnel service.

Recent tube replaceinent outages indicate an increased number of tubes which cannot be pulled 1nto the reactor. New tool development is required to

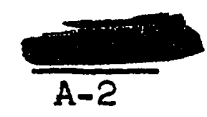



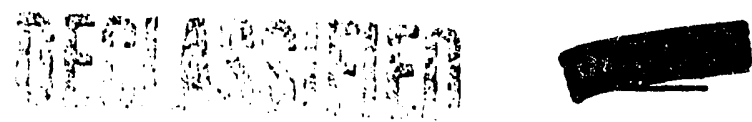

achleve tooling which w1ll perform channel straightening to correct tube pull-1n difficulties as well as reduce tube damage resulting from graphite abrasion.

\section{FACIIITIES ENGINEHRING OPERATION}

Adminlstration for the downcomer model testing program at Washington State University has been transferred to the Research and Englneering Operation.

A.report has been recelved from Mr. G. R. RIch, Consulting Engineer, listing his recommendations for lmproving the export water system. Additional information has been requested since his recomendations were not sufficiently detailed to permit design of the proposed modiflcations.

Over-all design completion for Project CGI-791 is 99.5 percent while detail design is $\$ \bar{y} .0$ percent complete. Both the aerosol generators and the smoke photometer are belng callbrated in preparation to develop a procedure for field checklng the absolute filters following installation.

Detail design for Project CGI-844 is 10 percent complete. Three speciflcations for engineered equipment have been approved.

Deta1l des1gn for Project CGI-883 is 33 percent complete. Requests for the purchase of englneered materlal have been transmitted for transformers, voltage regulators, grounding resistors, and motor control centers. Preliminary results of a study regarding the fessibility of installing the new 190-K low lift pumps prior to completion of electrical modif1cation-indicate that these changes are technically feasible; however, precautions will be required to Insure that the emergency electrical system is not overloaded.

Scope design for Project CGI- 884 is 90 percent complete; 80 percent of the detail design has been completed.

New prototype seals for the ball and flapper valves of the remote rear face installation were laboratory tested. Overboring work was reoriented toward a $550 \mathrm{mil}$ overbore at C Reactor, and satisfactory preliminary tests of process tube hardware designed for a somewhat lesser overbore were performed. An attempt to charge bumper slugs in $D$ Reactor ended when the slugs could not be charged through the existing channel curvature.

In NPR work, recommendations were made for a rear tube to nozzle joint and for nozzle closures. Three design tests were completed and inftial tests were performed on an expanded dump system evaluation test.

Washington State University has submitted a final proposal for the Columbia River Scale Model after acceptance of their facilities and personnel by the River Model Advisory Committee.

Following failure of two $4500 \mathrm{HP}$ motors, faulted coils in each unit were successfully isolated.

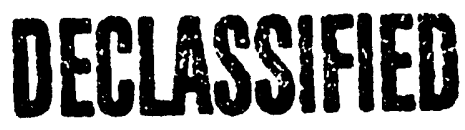




\section{- DEMAPIFI}

Columb1a River temperature contiol efforts were continued although results remain nominal due to continuing cool weather.

Appropriate tests of coal for the f1scal 1961 contract season were made.

An accelerated target schedule for beneflcial use of Reactor Confinement facilities (Project CGI-791) has been proposed by the AEC. This schedule requests beneflctal use in 100-F Area by October 21, 1960, and of all areas by January 22, 1961. The J. A. Jones Company has been asked to try to achieve this several months speed-up and to provide an estimate of the additional cost.

\section{NPR PROJECT OPERATION}

The Phase II bid package for the 109-N and 105-N Buildings wels 1ssued on schedule September 15, 1960. This package completed the majority basic design information 1tems for the Project. Major design activity will now be directed to acceptance testing, system descriptions, and vendor drawing review. Review of vendor Information has disclosed the need for additional design deta1l, Including such 1tems as anchor bolt data and the need for review of analytical primary loop transient studies on the integral relations of the many major pieces of equipment.

Concrete placement in the 105-N Bullaing during September, 1960, was at about 156 percent of the August rate.

Graphite machining continued to lag. Notching is now about three months behtind schedule. Procurement of graphite continued sat1sfactorily.

Fabrication and delivery of zircontum process pilot order tubes from Allegheny-Ludlum and Harvey Aluminum is satisfactory. Progress by Chase Brass on pilot order process tubes and Wolverine Tube for graphite cooling tubes is behind schedule. The production order of process tubes at Harvey Aluminum is ahead of schedule.

\section{FINANCIAL OPERATION}

Work in Process Inventory at June 30, 1960, was priced at current rates for comparison with book values. Minor discrepancies in the method of preparing the AEC Product report were discovered and changes recommended.

Essential Material and Frozen Lunch inventories were observed in $\mathrm{B}$ Processing on August 25, 1960.

Total number of personnel assigned to the Department at month end is 2,260 , a decrease of 15 from the prevlous month.

During the month, suggestion awards aggregatjng $\$ 934$ were paid to Department employees. Calendar year to date awards aggregate $\$ 5,185$. Authorized allocation for 1960 is $\$ 11,875$.

The absence and injury records pertinent to the 79-day period ended at midnight September 19, 1960 were examined. Nothing was found to prevent

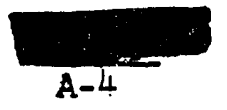


the Department from achleving the fourth consecut1ve HAPO General Manager's Safety Award.

\section{RELATIONS PRACTICES OPHRATION}

Three technically trained candidates were interviewed with no offers extended. Four monthly employees transferred into the Department from other HAPO and GE components; one employee transferred to another HAPO component; and four employees went on leave of absence. Six security violations occurred during the month.

\section{GEINERAI}

\section{RESPONSIBIIITYY}

Effective September I, the name of the former Plant and Industrial Engineering Operation was changed to Plant Englneering. A new component, Equipment Application Inglneering, was established within this operation.

\section{FORCE SUMMARY}

\begin{tabular}{|c|c|c|c|}
\hline & Bxempt & $\begin{array}{l}\text { Non } \\
\text { Exempt }\end{array}$ & Total \\
\hline $\begin{array}{l}\text { General } \\
\text { Research and Ingineering Operation } \\
\text { Manufacturing Operation } \\
\text { Facilities Engineerling Operation } \\
\text { NPR Project Operation } \\
\text { Financial Operation } \\
\text { Relations Practices Operation }\end{array}$ & $\begin{array}{r}2 \\
108 \\
389 \\
123 \\
78 \\
17 \\
7 \\
\end{array}$ & $\begin{array}{r}2 \\
64 \\
1364 \\
43 \\
30 \\
14 \\
19 \\
\end{array}$ & $\begin{array}{r}4 \\
172 \\
1753 \\
166 \\
108 \\
31 \\
26 \\
\end{array}$ \\
\hline TOTAL & 724 & 1536 & 2260 \\
\hline
\end{tabular}

SAFETY, SECURITY \& RADIATION EXXPERIANCE

Six securlty violations occurred. There were no disabling lnjurles or radiation exposures exceeding operational control. One hundred anc elght medical treatment injury cases were treated.

\section{INVENTIONS}

All persons engaged in work that might reasonably be expected to result in inventions or discoveries advise that, to the best of their knowledge and bellef, no inventions or discoverles were made in the course of their work during the perlod covered by this report except as listed below. Such persons further advise that, for the period therein covered by this report, notebook records, if any, kept in the course of their work have been examined for possible inventions or discoverles.

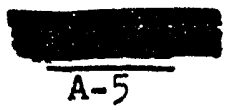




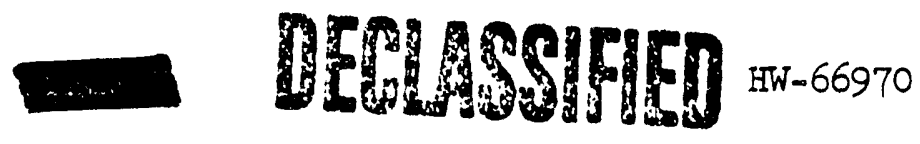

W. Dalos, "Electrical Clrcultry for a Time Delay Relay", September 24, 1960.

J. E. Hanson, "Hydraulic Pump-Flange-Bolt Tightener", September 27, 1960.

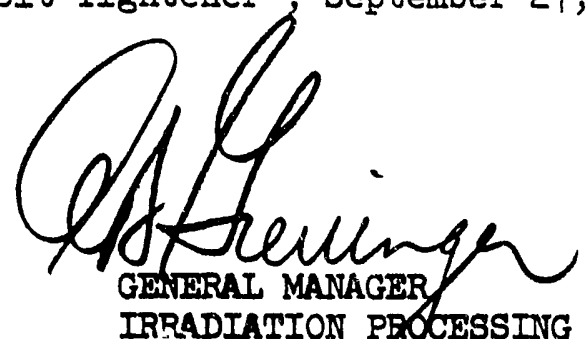

IRRADIATION PROCESSING DEPARTMENTI

$A B$ Greninger:OCS:bam
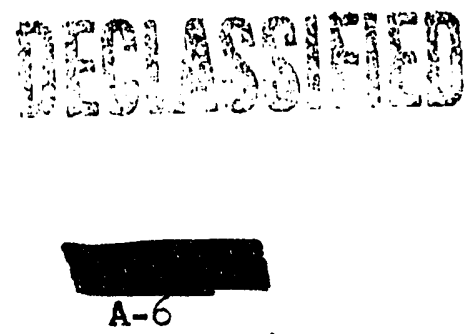


\section{EW -66970}

\section{RESEARCH AND ENGINEKGRING OPERATION}

PROCESS AND REACTOR DEVELOPMENT OPERATION

REACTOR FUELS

Present Reactor Technology

\section{DECLSSFFED}

\section{Profection Fuel Testing}

Five columns of self-supported fuel elements (end-spider support design) were charged into ribless tubes in B Reactor bringing the total to nine colums in reactor.

No additional installation of Zirconlum tubes was made in C Beactor. The total of 69 zircontum tubes underwent normal irradiation practices without incident during the past month.

Twenty colums of solld rall bumper fuel elements were charged into D Reactor during the September 11, 1960 outage. Ten of these columns contained four rail slugs. Also charged were ten colums of three rail slugs in which the rail between the ribs was omitted to permit the use of polson splines. Thermocouple probes were inserted in the downstream dumy patterns of six of the three-ribbed columns to determine the effect of this design on temperature uniformity in the coolant.

The Irradiation of four tubes of $1.47 \%$ enriched bumper elements in D Reactor was terminated September 24, 1960. Discharge was completed without incident. The factor of improvement over normal I\&W geometry fuel was 38 with a $95 \%$ confidence level.

\section{Advanced Reactor Technology}

\section{Elgh Temperature Irradiations - KGR Facilitieg}

The heavy walled single-tube elements in KFR Loop 3 continued under Irradiation without incldent. The elements have reached on estimated exposure of $970 \mathrm{MD} / \mathrm{T}$. The test w117 provide information on the behavior of an element similar in geometry to the 1nner tube of an NPR fuel element and w1 II in addition provide some irradiated fuel for in-reactor fallure testing.

The elght natural uranium tube-and-tube elements in KER Loop 4 continued under irradiation without incident. This charge has attained on exposure of approximately $1560 \mathrm{MW} / \mathrm{T}$.

KIRR Loops 1 and 2 are currently empty awaiting more charges now under preparation.

\section{Fuel Design Analysis}

The hydraulics portion of the IBM fuel design program was modified slightly to give agreement with flow laboratory determination of the drag produced

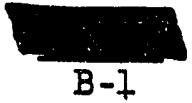




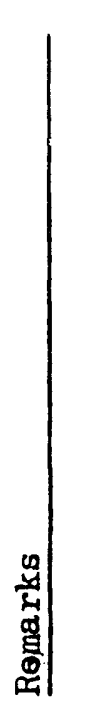

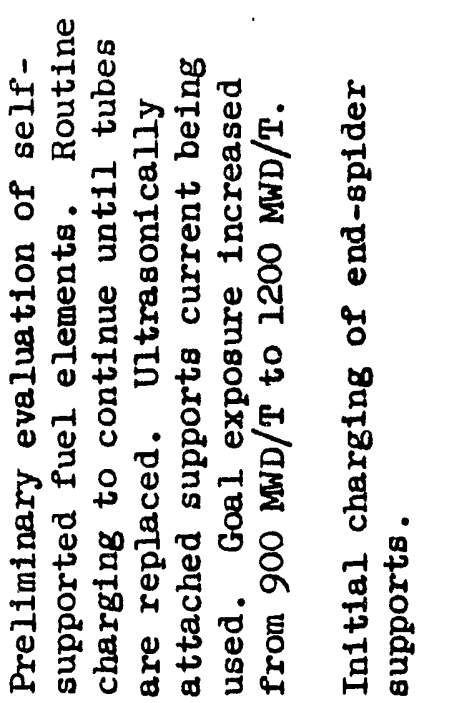

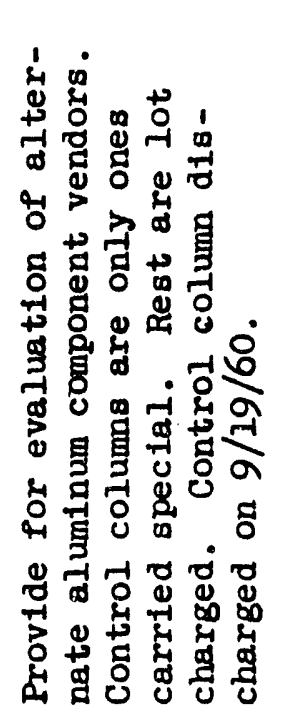

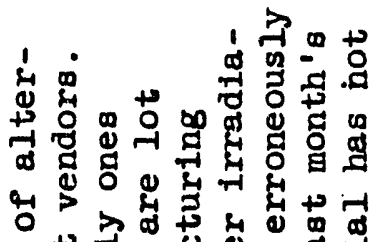

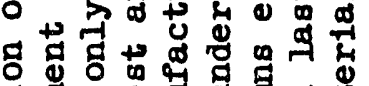

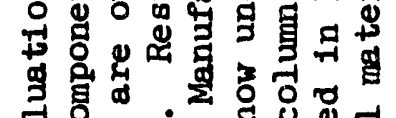

零

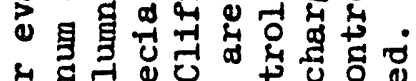

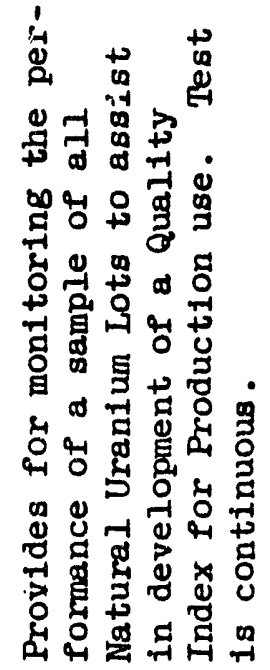

to

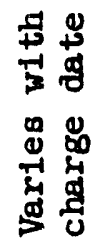

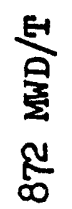

年

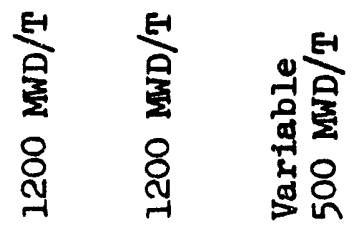

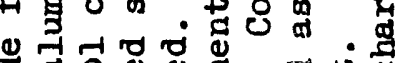

वै ने क्व

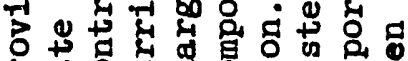

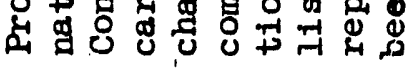

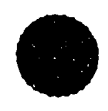

ou|

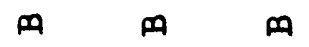

的

苟
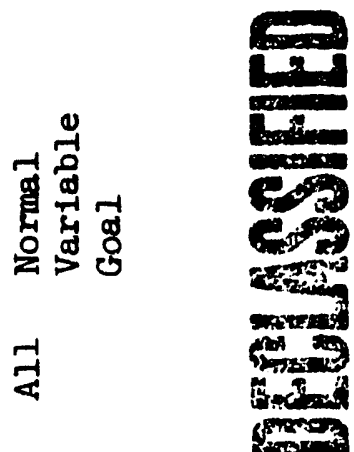

苟|

r $a$

$\mathfrak{N}$

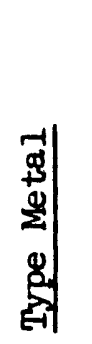

में

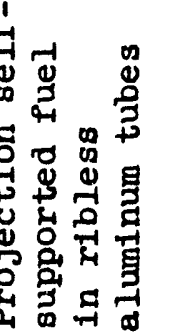

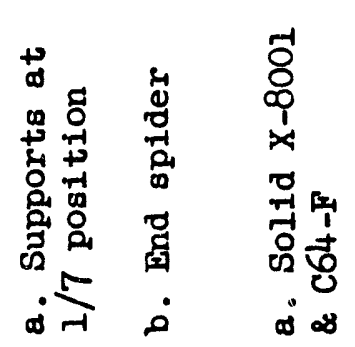

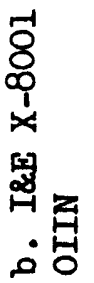

द्य

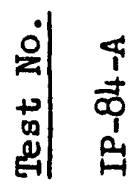

站

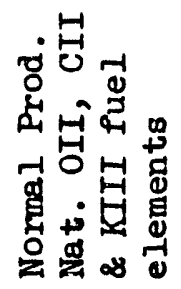

占

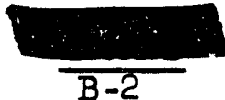


๘

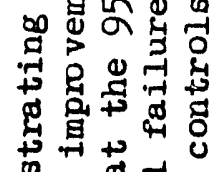

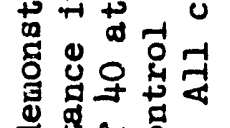

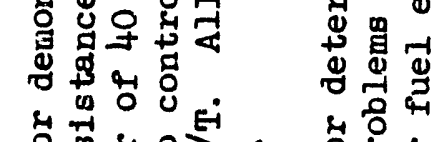

क्षे

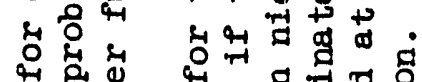

舟政会

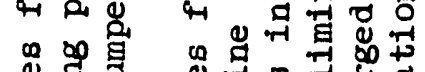

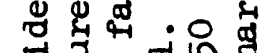

อี

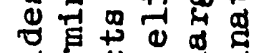

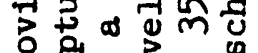

웅 영

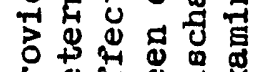

毡骂

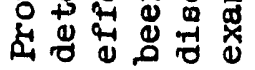
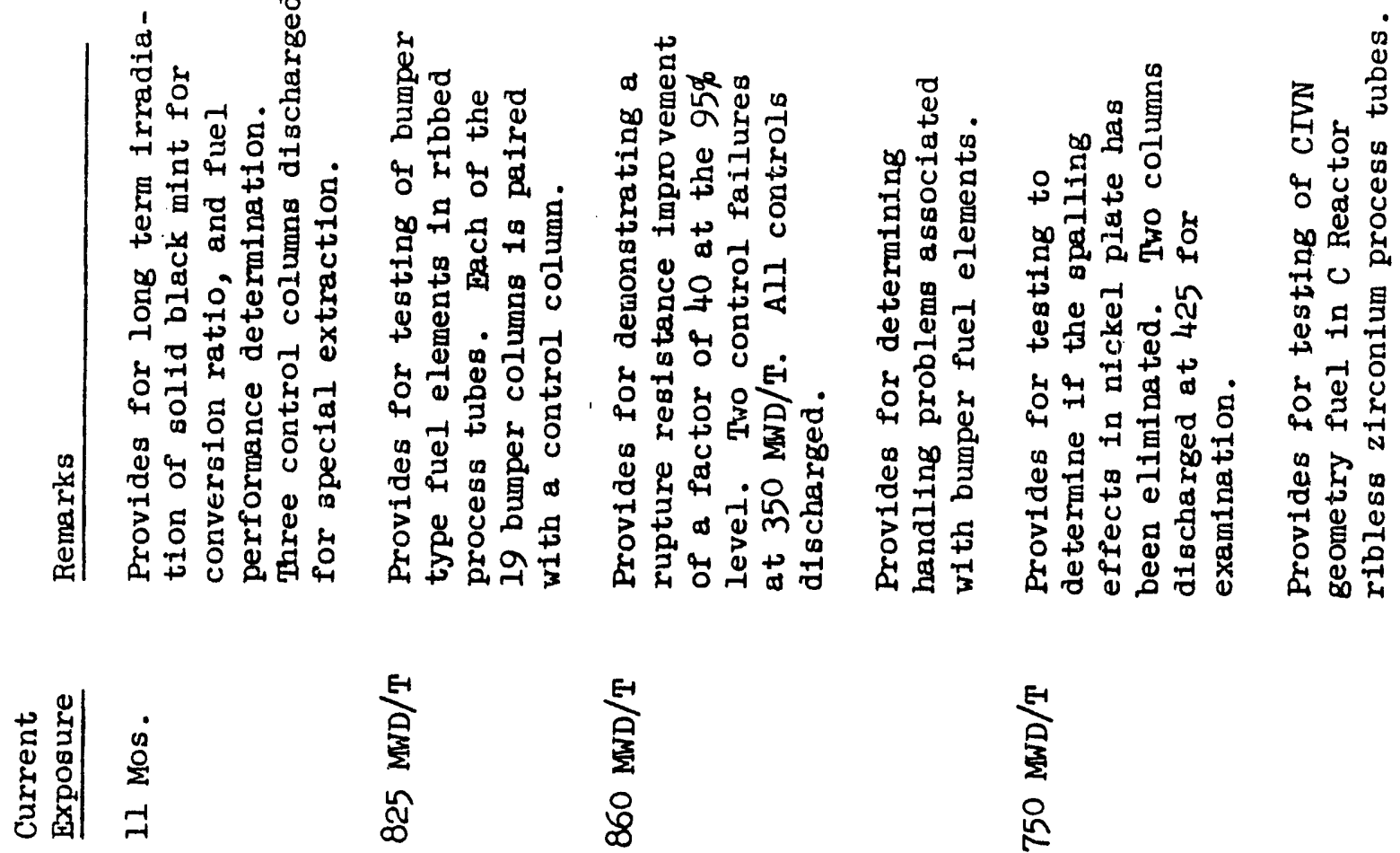

ลิ

突

롤

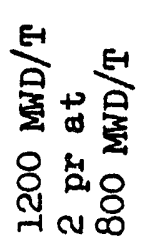

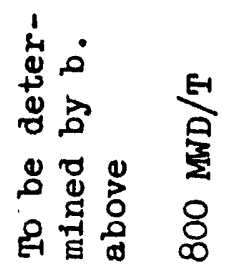

苟|

ค

$\sum_{\substack{n \\ \vdots}}^{\infty}$

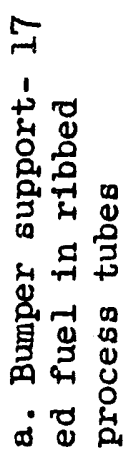

$+$

오

$\infty$

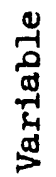

ㅁ 苔

o

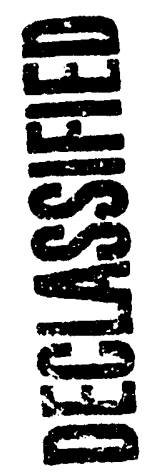

章

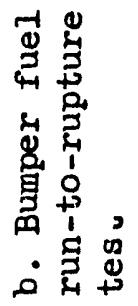

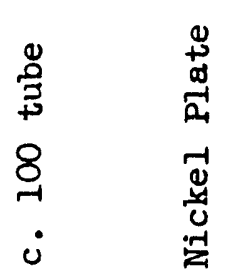

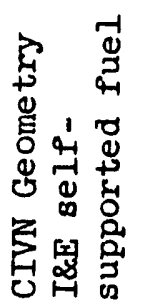

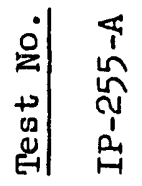

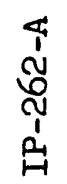

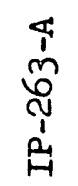

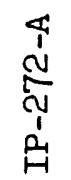

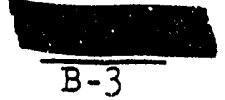




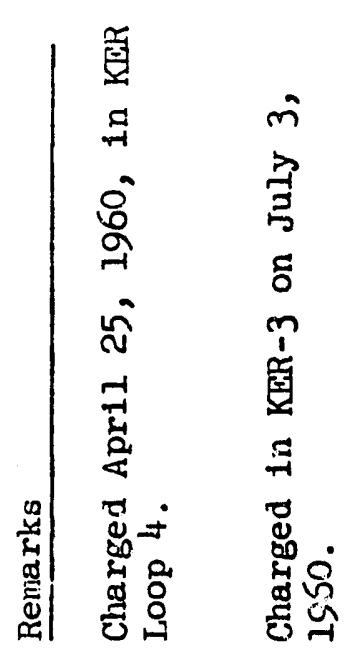

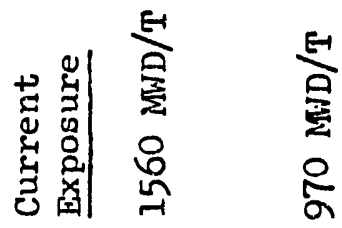

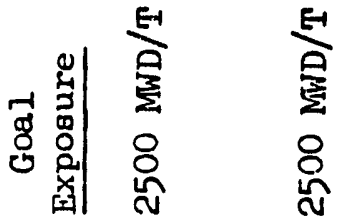

敋 国

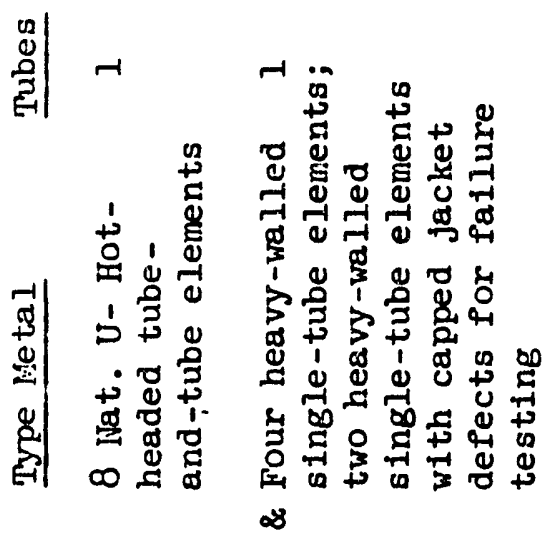

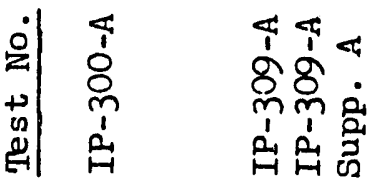

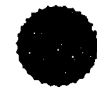

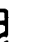


by "suitcase handle" supports. This completed a modification started last month.

A variety of potential fuel element candidates for the KER loops have been analyzed by the revised program. Among the possibilities investigated were: an early NPR inner tube enclosed in a $2 r-2$ sleeve utilizing both four and three supports at both ends of the fuel pleces; the present NPR inner tube ut1lizing again an inert sleeve of both natural uranium and a.974\% enrichment; large $1.6 \%$ enrlched fuel elements with an inert center rod; and a possible uranium dioxide $\mathrm{Zr}-2$ clad element for KER irradiations.

\section{REACTOR PEYSICS}

Present Reactor Technology

\section{E -N Conversion Ratio}

No results have yet been obtained from the isotopic analyses of enriched urantum and lithlum slugs irradiated earlier this year.

Speed of Control Studies

Studies have been fnltiated to investigate the effects of various powers and graphite temperatures from the standpoint of control speed. The se studies are directed at conditions which can exist during reactor startup as cpposed to equilibrium operation for which a considerable amount of analysis is already avallable. This work will continue.

Advanced Reactor Technology

\section{N Reactor Fast Flux}

An estimate of the neutron flux above $I \mathrm{Mev}$ in the NPR was made as a guide in programing experimental Irradiations of $\mathrm{Zr}$ in test reactors. The figure being used is $1.35 \times 10^{21} \mathrm{nvt} /$ year at $4000 \mathrm{MN}$.

\section{Critical Mass Studies}

Buckling measurements have recently been completed on $1 \%$ enriched uranium light water lattices ut1lizing NPR fuel geometries. Results obtained to date show the inftial assumptions on which $\mathbb{N}$ Reactor fuel element storage and handling were based were adequately conservative and no real critical mass problems exist in the facility as designed.

Monte Carlo Calculations

The Monte Carlo slowlng-down program has been completely debugged. A subroutine of this program was used to compute first-flight collisions of fast neutrons in concentric-cylinder fuel geometries. Previously the assumption had been made that the fuel water and cladding could be homogenlzed in obtaining collision probabilities in N Reactor fuel geometry. This assumption was checked with the following results. 


\author{
Collision Probability \\ Total \\ Uranium \\ $\mathrm{H} O \mathrm{O}$ \\ CIad
}
Monte Carlo
.4417
.3052
.1043
.0316

Homogenization Model

.4718

.3019

.1348

.0352

The Monte Carlo results are derived from 10,000 histories.

\section{N Reactor Physics Messurements}

The first koo measurement in the PCIR has been completed for N Resctor geometry. The value obtained was for a wet lattice from which the volds had been removed. The measured value of 1.069 was slightly lower than previously calculated. Work will continue to define experimentally the iv Reactor lattice parameters.

REACTOR EHGIIVBHRING

Present Reactor Technology

\section{Nozzle Testing}

Special reaned nozzles are undergoing miscellaneous tests to assure their suitability for use with bumper alugs. Included are impact, static internal pressure, cyclic torque, and cyclic temsile tests.

\section{Reector Reorlficing Studies}

An analytical and experimental program is underway to determine suitable reorificing systems for reactor fringe tubes loaded with I\&E fuel elements. Data indicates that desired flow rates cannot be obtained by a simple orifice at the front cross header because of the necessity of avolding cavitation during normal operation and the requirements on low trip pressure in the event of front connector fallure. Several possible solutions are under consideration.

\section{Charging Patterns - Flow Protection}

The effect of changes in the length of the downstream dumy charge on the flow protection was reviewed. Significant reductions in dumy charge length can be made with no appreciable effect on the TAI (Trip After Instability) Iimit. It is necessary to retain at least 24 " of perforated dumies downstream of the active charge.

\section{Advanced Reactor Technology}

\section{Decontamination}

Radiochemical analyses on samples obtained during the decontamination of KaRR-I are being made. Data from these samples shed some light on the distribution of activity deposited on piping, but no results are yet available.

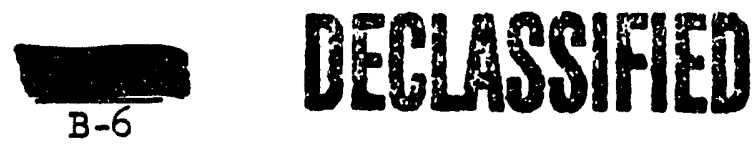




\section{DECLSSIFIED}

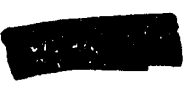

HW -66970

A long term corrosion test of bisulfate formulation has begun. The dissolved oxygen content of the water will be minimized to determine the effect of this step on the corrosion of the piping material.

NPR Graphite

Great Iakes Carbon Corporation contimues their efforts to purify four graphitizing furnace heats of reflector graphite which fail to meet the 25 dib purity specification. These four heats, if successfully completed, will complete the order for reflector graphite placed with Great Lakes.

Observation of the processing af bars for the NPR core by National Carbon. Co. revealed that the product is of apparent high structural quality. Chemical analysis and dih purity values of the first two shipments show that the material also meets the specification for nuclear purity.

Requests have been submitted to the AEC for assignment of two high fast flux positions in a testing reactor for the irradiation of test specimens of NPR core graphite. Preparation of these test specinens Irom the first bars delivered by National Carbon Co. Is underway.

RADIOLOGICAL ENGINAAGRING

Radiation Control Experience

The following table sumarizes the radiation exposure experlence of critical IPD classifications for the first 36 weeks of the 1960 badge year:

\begin{tabular}{|c|c|c|c|c|c|}
\hline Classification & $\begin{array}{l}\text { Total } \\
\text { Dose }\end{array}$ & $\begin{array}{l}\text { No. of } \\
\text { Employees }\end{array}$ & $\begin{array}{l}\text { Average } \\
\text { Dose/ } \\
\text { Dmployee }\end{array}$ & $\begin{array}{l}\text { Extrapo- } \\
\text { lated } \\
\text { Year End } \\
\text { Average }\end{array}$ & $\begin{array}{l}\text { No. of Employ- } \\
\text { ees over } 3 r \\
\text { Extrapolated } \\
\text { Exposure }\end{array}$ \\
\hline $\begin{array}{l}\text { Raciation Monftors } \\
\text { Processing Operators }\end{array}$ & $\begin{array}{l}165136 \text { m } \\
415066\end{array}$ & $\begin{array}{r}84 \\
250\end{array}$ & 1966 mor & $\overline{2840 \mathrm{~mm}}$ & 25 \\
\hline Plpefitters & $131681 \mathrm{mr}$ & 92 & $1431 \mathrm{mr}$ & $2379 \mathrm{mr}$ & 27 \\
\hline Millwrights & 103858 & 75 & $1385 \mathrm{mor}$ & $2000 \mathrm{mr}$ & 6 \\
\hline
\end{tabular}

Lapse of Control

Iapse of Radiation Control

Processing

Maintenance

Supplemental Crews

Research \& Engineering

Facilities Engineering

Central Maintenance

Reactor Areas

Assigned Totals

IPD General

Outside IPD

$\begin{array}{ll}\frac{B}{0} & \frac{C}{0} \\ 0 & 0 \\ 0 & 0 \\ 0 & 0 \\ 0 & 0 \\ 0 & 0 \\ 0 & 1 \\ 0 & 1\end{array}$
Distribution by Reactor and Component

\begin{tabular}{ccccccc}
\hline D & $\frac{D R}{1}$ & $\frac{F}{2}$ & $\frac{\text { H }}{2}$ & $\frac{K E}{2}$ & $\frac{K W W}{2}$ & $\frac{\text { IPD Totals }}{8}$ \\
0 & 0 & 0 & 0 & 0 & 0 & 0 \\
0 & 0 & 0 & 0 & 1 & 0 & 1 \\
0 & 0 & 0 & 0 & 0 & 0 & 0 \\
0 & 0 & 0 & 0 & 0 & 0 & 0 \\
1 & 0 & 0 & 0 & 0 & 0 & 1 \\
0 & 1 & 1 & 0 & 0 & 0 & 2 \\
2 & 3 & 3 & 1 & 2 & 0 & 12
\end{tabular}

1

Vertical columns do not necessarlly add up to the assigned totals, because in some cases, a lapse of Control is chargeable to more than one component.

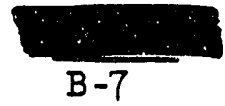


Beginning this month the total effluent activity by reactor is deleted from this report. Instead the concentration of 1sotopes of concern in effluent water w1ll be reported. Samples for 1sotoplc analysis are taken weekly except in the case of chromium-5l for which only one analysis per month for each reactor is run.

\begin{tabular}{|c|c|c|c|c|c|}
\hline Reactor & $\mathrm{P}^{32}$ & $\mathrm{As}^{76}$ & $\mathrm{zn}^{65}$ & $\mathrm{~Np} 239$ & $c_{x^{51}}$ \\
\hline$B$ & 17 & 170 & 6 & 135 & 280 \\
\hline C & 12 & 155 & 16 & 125 & 150 \\
\hline D & 7 & 80 & 8 & 205 & 320 \\
\hline $\mathrm{DR}$ & 10 & 125 & 9 & 225 & 300 \\
\hline$F$ & 14 & 100 & 23 & 95 & 180 \\
\hline H & 12 & 90 & 11 & 100 & 160 \\
\hline KE & -- & $=-$ & - & -. & 80 \\
\hline $\mathrm{KW}$ & 5 & 75 & 11 & 60 & 120 \\
\hline
\end{tabular}

For 1sotopes other than $C^{51}$ the values quoted are the averages of the weekly analysis. The numbers are in units of micro micro curies/cc.

\section{Reactor EPfluent Water Investigations}

The effluent treatment tests at 107-D where the effluent water is being passed through a ked of aluminum turaings have advanced from tests which largely duplicated laboratory work to tests at hlgher flow rates. The Initial tests showed the same efficlencles for reduction of critical isotopes as did the laboratory tests. Dose rates from the sides of the tank increased from $300 \mathrm{mr} /$ hour to $800 \mathrm{mr} / \mathrm{hour}$ when the flow rate was doubled. This indicates that the efficlency for detalning the shorter lived nuclides was not reduced by the change in flow.

A half-reactor test at 100-H substituting aluminum nitrate for aluminum sulfate in process water treatment was started September 16. This test is intended to demonstrate the amount of reduction in the output of phosphomis-32 that can be achieved by removing more than 90 percent of the phosphorus and half the sulfur from the influent water. The feed rate was increased from 12 ppm at the start of the test to $25 \mathrm{ppm}$ on September 21. Since that time the pH of the process water on the test side has been controlled by adjusting the aluminum nitrate feed. No difficulties in the water treatment plant nor in reactor operation have been encountered. Therefore it does not appear that addition of nftric acld for $\mathrm{pH}$ control will be required until river water quality deteriorates in the spring.

Another half-reactor test started at 100-B on September 16. Because of the uncertainty surrounding the importance of sulfur as a precursor to phosphorus-32 and in order to demonstrate the effectiveness of conventional and less costly aluminum sulfate to remove critical 1sotopes, this test duplicates the test at 100-H except that the sulfui: in the influent water is not reduced. The feed rate of alum on the test side was increased to $10 \mathrm{ppm}$ on September 16 and further increased unt1l it reached $20 \mathrm{ppm}$ on September 22 . It will remain at that level for the duration of the test. No difficulties have been experienced and none are anticipated.

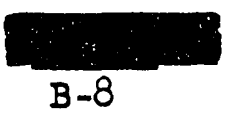


Calculations were made to determine the maximum permissible concentration (MPC) in air for effluent water deposition products which are a primary source to airborne contamination in the reactor discharge areas. The MPC was calculated to be $1 \times 10^{-7} \mathrm{uc} / \mathrm{cc}$, and the critical organ is the lung. 
PROCESS TECHNOIOGY OPRRATION

\section{DECLASSFFED}

RRACTOR POWER IEVEL ITMITATIONS

The primary power level limits at $C, K E$, and $K W$ Reactors was based on fuel element fallure control, and the power levels at B, D, DR, F, and H Reactors were primarily restricted by bulk outlet temperature limitations.

WATHER TREATMEATI

Aluminum Nitrate Test

100-H water treatment plant started feeding approximately $28 \mathrm{ppm}$ aluminum nitrate on September 2l, 1960, on the west side. No difficulties occurred. Water quality is good and filter headloss 1s low. Filter rates have not been high enough to establish water plant capacit: using the high feed rates.

High Alum Test

100-B water treatment plant started feeding $20 \mathrm{ppm}$ alum on September 21, 1960, on the north side. Water quality is good and filter headioss is low. Inttially, fllter runs dropped to four hours due to breakthrough. Thereupon, approximately $0.003 \mathrm{ppm}$ Separan was added snd the runs lengthened to 10 hours.

Pasco Water Treatment Plant

As * result of better monitoring of flitered water suspended mater fals, alum feeds have been reduced by 50 per cent and sodium carbonate feeds have been eliminated.

FROCESS STANDARDS

EW -46000 B, Process Standards - Reactor

Four revised standards were issued during the month. These were:

Process Standard C-090 - "Inoperable Rods and Ball 3X Hoppers During Reactor Operation"

The restrictions imposed upon the number of horizontal rods that may be out of service during reactor operation were removed from the standard. The number of horlzontal control rods in service during operation is no longer a reactor safeguard consideration, since they are not considered in total control calculations during operating periods. Only rods in the reactor are considered for reactivity control under the Total Control Criterion.

Process Standard D-070 - "Reactor Confinement - Fog Spray System"

Functional testing requirements for the fog spray system were transferred to the Process Equipment Standards manual, HW-41000.

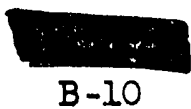


Functional testing requirements previously contained in Process Standard D-O70 were deleted. A reference to the equipment standard was added to the reactor standard.

\section{Process Standard F-011 - "Process Materials" (POison Material)}

Due to manufacturing difficulties associated with dispersing cadmium in an aluminum-silicon alloy, the cast uncanned, tubular Al-Si-Cd dumiles are not believed to be the cheapest neutron absorbing material available. However, approxtmately 2600 unused Al-Si-Cd dumies remain from a production test.

Provisions for use of uncanned, tubular Al-S1-Cd poison dumies, drawing number $\mathrm{H}-1-1 \mathrm{I12}$, have been added to this standard. Testing under Production Test IP-174-IF, HW-59627, showed that reactor safety and life considerations will not be compromised by use of the poison dumies.

\section{Process Standard F-Oll - "Process Materlals" (Chemicals)}

Chromic ac1d and Turco 4306-B have been added to this standard as acceptable for reactor decontaminating agents.

Formerly, decontamination of test hole facilities or traverse tubes was accomplished under provisions of an approved production test. Sufficient data existed to permit use of chromic acid under limited conditions, for decontamination of these facilities. Turco $4306-\mathrm{B}$ is presently limited to decontamination of reactor rear face piping, under closely controlled flow conditions. The standard prohibits use of Turco 4306-B solution through reactor, or in contact with zirconium tubes.

EW $-46000 \mathrm{D}$, Process Standards - Reactor

One revised standard was issued during the month. This was:

Pracess Standard C-090 - "Inoperable Rods and Ball 3X Hoppers During Reactor

Revisions to this standard are identical to those for HW $-46000 \mathrm{~B}$, above.

HW-46000 F, Process Standards - Reactor

Three revised standards were issued during the month. These were:

Process Standard C-090 - "Inoperable Rods and Ball 3X Hoppers During Reactor Operation"

Process Standard D-070 - "Reactor Confinement - Fog Spray System"

Process Standard F-Oll - "Process Materials" (Chemicals)

Revisions to these standards are identical to those for $B M-46000 \mathrm{~B}$, above.

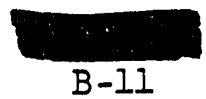




\section{$\mathrm{HW}-46000 \mathrm{H}$, Process Standards - Reactor}

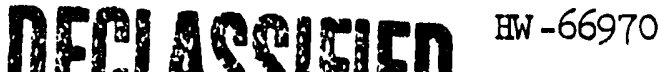

Two revised standards were 1ssued during the month. These were:

Process Standard D-070 - "Reactor ConfInement - Fog Spray System"

Process Standard F-011 - "Process Material" (Chemicals)

Revisions to these standards are ident1cal to those for HW-46000 B, above.

HW -46000 K, Process Standards - Reactor

Four standards were 1ssued during the month. These were:

Process Standard C-090 - "Inoperable Rods and Ball 3X Hoppers During Reactor Operation"

Process Standard F-Oll - "Process Materlals" (Chemicals)

Revisions to the se standards are identical to those for HW $-46000 \mathrm{~B}$, above.

$\frac{\text { Process Standard K-010 - "1706 KGR Recirculation Facility - General Require- }}{\text { ments" }}$

The former, more restrictive, operating limits for KRR Ioop \#I resulted from uncertainties in metallurgical test data of the original process tube. Recent installation of a new, thoroughly tested zircaloy-2 process tube now permits increased operating limits consistent with Ioops 2,3 , and 4 .

Pressurizer safety valves and rupture disc settings were reduced to 1720 psig for all KGR loops. A maximum rate of pressure change during hydrostatic pressure testing was added to minimize the possibility of over-stressing the process tube.

Process Standard K-040 - "1706 KER Recirculation Facility - Recirculation With Fissionable Charge"

This revision authorized a 15 psi increase in annunciator setting of the tube's exit pressure for operational latitude.

\section{PROCESS CBANGE AUTHORIZATIONS}

Elght Process Change Authorizations were issued during the month to permit temporary deviation from Process Standards - Reactor, HW-46000, and three Process Change Authorizations were 1ssued to permit temporary deviation from Process Standards - Water Plant, HW-27155 RevI. These were:

PCA $\# 0-75-" B 1$ swoth Irradiation in Front-TO-Rear Test Holes - KE Reactor"

The $K$ Reactors have several front-to-rear test holes which are normally used for irradiation of special request materlal. The test holes contain two

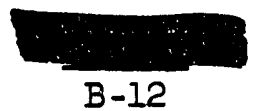


concentric aluminum tubes, each having a separate coolant header.

When the test holes are not loaded with special request charges, it is desirable to gainfully use them for irradiation of bismuth material. Frontto-rear test hole 3674 has been temporarily assigned to $\mathrm{KE}$ Processing Operation for production use.

The operating requirements and limtts for these tubes are not specifled in Process Standards since they are not normally used for production purposes. However, since 3674 is belng used for blsmith 1rradiation, appropriate operating limits were specified in the PCA.

PCA \#0-76 - "Water Leak - H Reactor"

Process Standard B-010 specifles that the reactor shall be shut down when water collection rate from the gas atmosphere exceeds 24 gallons per day.

On August 6, 1960, the collection rate slightly exceeded the specified max1 mum rate permitted in the referenced standard. No loss of reactivity was observed, which indicated a leak outside the active zone of the reactor.

Authorization was given to continue operation until August 15, 1960, at which time marpower scheduling could be efficlently arranged. Reactor shutdown was specifled if any of the following conditions occurred: dewpoints in excess of $15 \mathrm{~F}$, water collection rate greater than 50 gallons per day, or any unexplained loss of total or local reactivity.

PCA \#0-77 - "Vert1cal Bowlng Traverse Delay, H Reactor"

Process Standard G-010 specifles that vertical bowlng of a top center process tube be taken every three months. Vertical bowing measurements were due during the July shutdown. Several extra outage hours would have been necessary in order to accomplish this requireinent.

Authorization was glven to defer taking these data to not later than September 26, 1960, since the previous bowling data showed no significant changes in graphite distortion.

PCA \#0-78 - "Export line Backup - Raw Water - F Reactor"

Water Plant Standard 190-B-070 specifies that "upon loss of normal electrical power at B, D, F, or $\mathrm{B}$, an emergency steam pump shall be placed on the export system in the area losing power, within 10 minutes, unless it is determined within that time that $B$ and $D$ were not involved in the electrical outage and export Iine pressure is normal." The steam pump which provides the above backup at $F$ Reactor was removed from service for needed repairs at $8 \mathrm{a.m.}$, on August 16, 1960. Due to the extremely remote posstbillty of an extended loss of BPA power at all four reactor areas (100-B, 100-D, 100-F, and 100-H) concurrent with loss of steam at $100-B, 100-D$, or 100-H, continued operation at F Reactor was feasible.
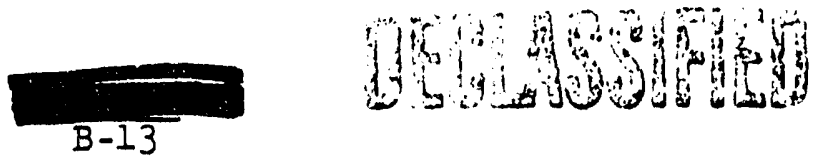
This process change authorized continued operation at $F$ Reactor for 48 hours with the emergency steam pump on the export system out of service.

PCA \#0-79 - "Export Iine Backup - Raw Water - F Reactor"

This PCA essentially extended the provisions of PCA \#0-78. This was desirable as repair to the emergency steam pump required approximately 48 hours longer than orlginally estimated.

PCA \#0-80 - "Thermal Shield Cooling, K Reactors"

Process Standard A-070 specifies temperature limits for the reactor bottom shield cooling water and the concrete pad directly below the thermal shield. Difficulties have been encountered in meeting the se temperature requirements. The limits are specified to control the thermal gradient through the concrete pad.

Operating experience has shown that the thermal gradient in the pad is well below the value whlch might cause damage to the pad.

Authorization was given for a 40 per cent increase in the maxdmum outlet temperature limit for the bottom thermal shleld cooling water and a 20 per cent reduction in the lower limit specified for the pad. The temperature differential mast not exceed 25 C. This authorization will explre october 31, 1960, or upon revision of the referenced standard, whichever is sooner.

FCA \#0-81 - "H1gh Graphite Temperature - DR Reactor"

Process Standard C-040 specifles graphtte temperature limits for reactor operation. On August 18, 1960, the maximum graphite temperatures at DR Reactor rose to approximately $40 \mathrm{C}$ over graphite temperature limits. Operation of the reactor was continued under the "Bmergency Conditions Only" provision in the referenced standard which allows continued operstion for 24 hours if the peak graphite temperature achieved is $40 \mathrm{C}$ above temperature limits. During this allowable time, a program of power level reduction, gas atmosphere variation and rod movements was inftiated under the direction of the reacto: physicist to reduce graphite temperatures to within limits.

Cont1lued operation was permitted with the graphite no more than $40 \mathrm{C}$ above the linit specified in the referenced standard for an additional 24 hours, provided the program for reducing graphite temperature to within limits was continued.

FCA $70-82$ - "Iow Graphite Temperature, DR Reactor"

Process Standard C-040 specifies graphtte temperature limtts for reactor operation. Due to graphite temperature cycling in the non-equilibrium period following recovery from a $\#$ il safety circuit trip, it was necessary to operate whth lower than specifled graphite temperatures to provide adequate control of the reactor.

Authorization was given to continue operation with graphite temperatures no

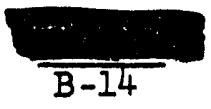



more than $25 \mathrm{C}$ below the limit specifled in the referenced standard for a
maximum perlod of 24 hours.

PCA \#0-83 - "Export Ine Back"2D, Raw Water - F Reactor"

Water Plant Standard 190-B-070 specifles that "upon 1088 of normal electrical power at B, D, F, or H, an emergency steam pump shall be placed on the export system in the area losing power, within 10 minutes, unless it is determined within that time that $B$ and $D$ were not involved in the electrical outage and export line pressure is normal." The steam pump wh1ch provides the above backup at $I$ Reactor was removed from service for needed repair to the speed reduction year on August 24, 1960. Due to the extremely remote possibility of an extended loss of electrical power at all four reactior areas (100-B, $100-D, 100-F$, and 100-H) concurrent with 1088 of steam at 100-B, 100-D, or 100-H, continued operation at F Reactor was feasible.

Th1s process change authorized continued operation at F Reactor with the emergency steam pump on the export system out of seivice unt1 I August 29 ,
1960 . PCA $\# 0-84$ - "Water Ieak - DR Reactor"

Process Standard B-010 spec1fies that the reactor shall be shut down when the water collection rate from the gas atmosphere exceeds 24 gallons per day.

On August 27, 1960, the water collection rate slightly exceeded the specified mardmum rate permitted in the standard. No reactivity loss was observed which indicated the leak was outside the active zone of the reactor.

Based on the above conditions, authorization was given to continue operation until September 1, 1960. Reactnr shutdown was required if any of the following conditions occurred: dewpolnts in excess of $15 \mathrm{~F}$, water collection rate greater than 50 gallons per day, or any unexplained loss of total or local
reactivity.

$\frac{\text { PCA } \# 0-85 \text { - "Removal of High Pressure Crosstie Flow Limiting Orifices, K }}{\text { Reactors" }}$

Removal of the flow Ilmiting oriflce from the high pressure crosstie was planned. Concurrently, safety circult changes were to be made which would delay opening of the V-73 valve until five seconds after the alding reactor has been shut down.

This FCA presented a valving procedure to be used at a shutdown $K$ Reactor to minimize the amount of coolant that could be diverted to it from the other $\mathrm{K}$ Reactor.

\section{PROCESS ASSISTANCE}

Auditing

One englneer audited the conformance to Process Standards by making 17 in-
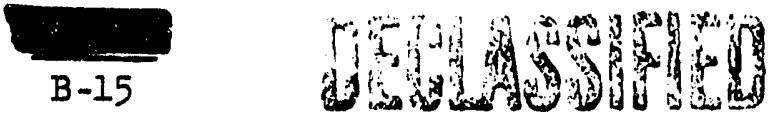
spections at each reactor during the report period.

Graphies

Graphic services prepared 30 charts, graphs, and visual alds for various IPD and HIO components.

RUPIURE EXPFARIFINCS

\begin{tabular}{|c|c|c|c|c|c|}
\hline $\begin{array}{l}\text { Fallure } \\
\text { Date }\end{array}$ & $\begin{array}{l}\text { Tube } \\
\text { Number }\end{array}$ & $\begin{array}{l}\text { Lot } \\
\text { Numbex }\end{array}$ & $\begin{array}{l}\text { Type of } \\
\text { Material }\end{array}$ & Exposure & $\begin{array}{l}\text { Type of } \\
\text { Failure }\end{array}$ \\
\hline $\begin{array}{l}9 / 23 / 60 \\
9 / 24 / 60 \\
9 / 25 / 60\end{array}$ & $\begin{array}{l}1486-C \\
1960-D \\
0684-D R\end{array}$ & $\begin{array}{l}K J-239-D \\
V I-037-D \\
K H-208-D\end{array}$ & $\begin{array}{l}\text { I\&E N } \\
\operatorname{ILE} \mathrm{N} \\
\operatorname{ILE} \mathrm{E}(0.94 \%)\end{array}$ & $\begin{array}{l}577 \\
640 \\
118\end{array}$ & $\begin{array}{l}\text { S1de Hot-Spot } \\
\text { S1de Hot-Spot } \\
\text { Mechanical } \\
\text { Damage }\end{array}$ \\
\hline
\end{tabular}

Iegend:

I\&S E - Th1s is the symbol for internally and externally cooled production reactor fuel elements with uranium cores enriched in U-235. The welght per cent U-235 in the core material is stated.

Ise N - This is the symbol for internally and externally cooled production reactor fuel elements of natural uranium.

Side Hot-Spot - The faliure was probably caused by accelerated corrosion of the external can-wall in a localized region of high temperature.

Mechanical Damage - The fallure was probably caused by mechanical damage of the fuel element before 1madiation. 
Flattening efficlency remained high with the total ECT above 77 percent for the eighth consecutive month. However, flattening efficlency continued to be somewhat reduced at some reactors because of the decreased incentive while operating on bulk outlet temperature rather than individual tube power limits. Nonequilibrium losses tended to be lower for those reactors limited in level by bulk effluent temperatures because of the greater flexibility to permit flux distributional unbalance under pre-equilibrium conditions.

SUMMARY OF OPERATIING DATA OF PHYSICS INTIEREST FOR TIEE MONTH OF SEPTIEMBER, 1960

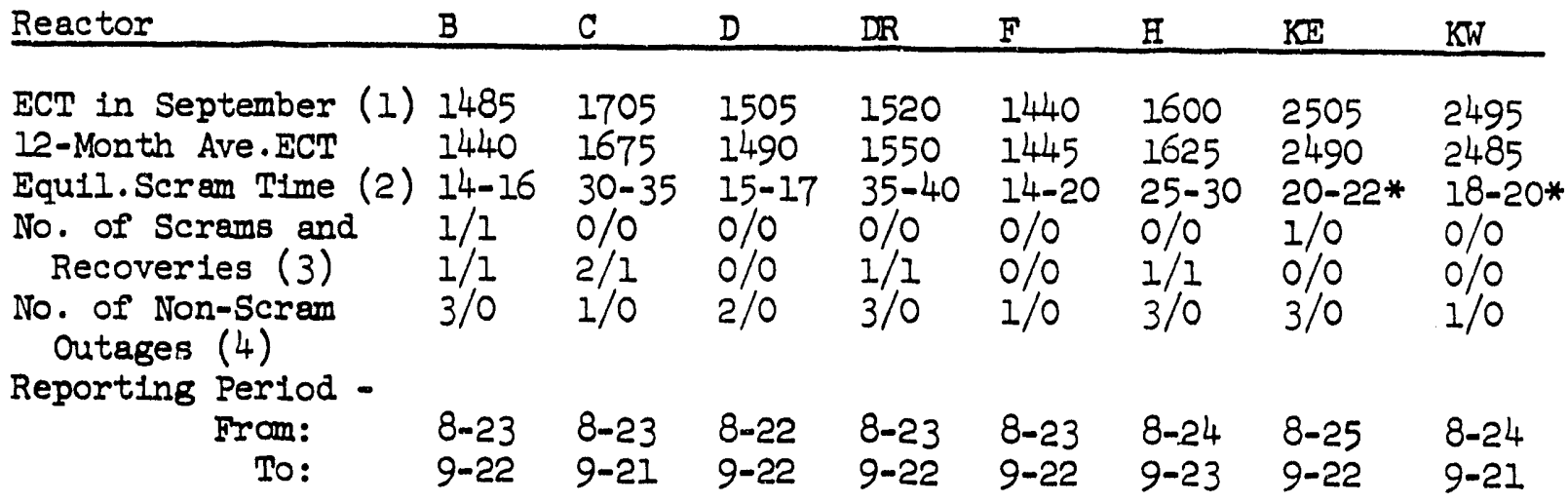

*Equilibrium scram recoveries are not attempted at the $K$ reactors.

(1) Effective Central Tubes; this value is defined as pile power level divided by the average of the ten most productive tubes in the reactor.

(2) This is defined as the maximum time available in minutes between scram and first indication of startup.

(3) The first pair of numbers shows the number of brief outages from which secondary cold startups would be made and the number of successful startups. The second pair shows the number of brief outages from which hot startups would be made and the number of successful recoveries.

(4) The first number shows the number of ordinary outages (including those initiated by scrms followed by unsuccessful recovery attempts), and the second shows the number of additional outages to discharge temporary poison. 
Although three outages interrupted operating continulty, and shortage of reactivity following one outage hampered reactor control and limited the pile power level, a new high average ECT was attained.

A fallure to make turnaround during the startup on 9-3-60 was due to a flux distortion which reduced the worth of the top part of the HCR system below the calibrated values which are based on a balanced flux distribution. As the size of the radial flattened zone has been increased slightly for higher operating efficiency, minor startup control problems have been experienced due to the decreased capacity of the HCR system to control top to bottom heat shift tendencies as equilibrium conditions are approached.

\section{Reactor - D. E. Newbrough}

Only one outage interrupted the operating continutty. Improved flux distribution control, primarily fram the installation and initial application of the zone temperature monitors and increased utilization of the spline system, resulted in a nonequilibrilm loss of only 0.16 effective equilibrium day following the cold startup and 0.04 effective day following a scram recovery.

Forty more of the special front enrichment loadings, designed to correct for the downstream flux distortion resulting from $3 x$ balls in the front lattice, were charged this month bringing the total so charged under PT IP-324-C to seventy-three. Preliminary Plux distributional data with the first 33 charges indicated about the expected improvement in the axial flux distribution.

\section{Reactor - J. F. Jaklevick}

The installation and successfur application of a spline coller has permitted full use of the spline system for startup control. A nonequilibrium loss of only 0.20 effective day after an infinite outage resulted from the use of 60 startup splines, representing an improvement of about 0.40 effective day less production loss than would have occurred with the former limit of 20 splines per startup.

Although one startup occurred with a partially wet reactor lattice, startup efficlency and subsequent equilibrium operation were hindered only slightly.

\section{DR Reactor - D. G. Montague}

The reactor was shut down on schedule September 8 to recharge the entire central zone (980 tubes) for the third time. A distributional flux shifting problem was experienced following a hot startup on 8-26-60 and continued for the two weeks preceding the outage for the full central zone discharge. Plans have been made for alleviating this problem when the newly charged load reaches high exposure in about three months.

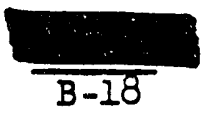




\section{IR Reactor - D. G. Montague (Cont'd.) H(S)}

The variations in gas composition permitted by the remotely operated pile gas system have also contributed to the distributional control problem; however, a new gas control system is being installed which w1ll permit operation of the gas composition from the control room.

Followlng the biock discharge only 0.15 effective day startup loss occurred with the good flux distribution stability at low residual exposure and the operation on a bulk effluent limit somewhat below tube power limits.

\section{F-Reactor - C. D. Willkinson}

Increased numbers of splines were used for flattening, and four splines were used to permit a blgher turnaround level. No significant difficulties have been encountered with the spline chopper.

Startup levels were limited predominately by TAI limits of the fringe zone tubes which were not yet equipped with reamed venturis.

Operating continulty was interrupted by only one scheduled outage during the report period.

\section{E Reactor - A. R. Kosmata}

The twenty-eight plece loadings charged into the central zone of the reactor to reduce metal cycle costs accompanylng the lnitial central zone block discharge have decreased the radial flattening efflclency slightly; however, the power level continued to be limited only by bulk outlet temperature limits. A desired increase in relative flux in the front of the reactor resulted from the displaced short charges and the heavy downstream loading of Pb-Cd slugs in the PCCF system prior to the block discharge scheduled early in October. To avold control problems at the current high exposure status all PCCF adjustments were performed during nonequilibrium operation, and compensation for all long-term reactivity gains during equilibrium operation was accomplished by gas composition and horizontal control rod adjustments, a technique which works satisfactorlly with the larger fifteen control rod system at $\mathrm{B}$ Reactor.

A comparison in temperature between an original imbedded filler block thermocouple and an 1mediately adjacent geminol stringer couple showed that the imbedded couple read an average of $90 \mathrm{C}$ lower in temperature; other observations also indicate that the original imbedded couple is failing.

KE Reactor - G. F. Balley

The newly installed rapld temperature scanner, which samples 50 tubes in rapid succession in a manner somewhat similar to the pop-corn popper in the old reactors, has significantly alded the rise to equilibrium power following startups; distributional flux shifting has been reduced considerably. Operational continulty was intermpted by one rupture in solid natural

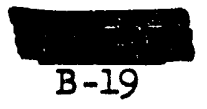




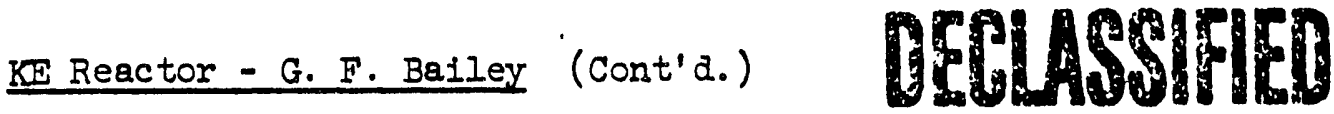

material and by occurrence of a split spline cap seal during a spline removal operation.

Flattening efficlency and nonequilibrium losses were maintained at the normal favorable levels characteristic of spline usage.

KN Reactor - R. A. Chitwood

The poison column displacement facillty has operated satisfactorily, although monftoring of its effect on the flux distribution has been prevented by the inoperability of the traveling wire flux monitor.

The subcritical monitor drive systems continue to function improperly. Startup and flattening efficlency were normal, although a flux distortion limited the initial startup level following the one outage during the report period.

\section{PROCESS PHYSIC'S STUUTES}

Safety Control Studies

It is difficult to evaluate the total control requirements. or capacity for a given fringe poison and compensating enrlchment loading pattern. A general analytical solution has been developed for assuring that the combined fringe polsoning and enrichment loading control requirements do not exceed those of a natural uranium fringe loading; an empirical tube power comparison under equilibrium conditions is used as a test. A document explaining the analytical derivation and its application w1ll be issued soon.

\section{Pile Reactivity Studies}

An accountability anomoly in the conversion ratio for $C$ Pile enrichment has been traced to use of out-dated lattice calculation information in the 709 program; appropriate changes in the program have been inftiated.

A full-time assignment has now been made to initiate NPR startup physics test preparation.

\section{Control Efficlency Studies}

D Reactor, with the use of its new coller, carried out a 60-spline startup with a net loss of only 0.2 effective day. Spline collers are targeted for the other old reactors by March 1, 1961.

Four poison displacement columns, out of the six-column prototype system, have now been placed in the KW Reactor. Difficulties were encountered in elevator clearance in the two bottom locations; the other two will be charged in the near future.

A study was carried out by Process Technology, supported by Reactor Physics and Operational Physics, to indicate the incentives of using bumper slugs in the E-N program. These studies indicated an appreciable gain in the use of bumpers for the $\mathrm{E}-\mathrm{N}$ loading over and above the large gain predicted for 
use of bumpers with natural uranium.

"Justification for Development of an Automatic Distributional Control System" was published during the month as HW-66818.

\section{Shielding studies}

A factor of two improvement in neutron dosage rates was observed on the $B$ Pile front face following replacement of steel shielding in dry columns with bigh density concrete. A document describing these measurements and their results is currently ready for publication. A similar measurement at the C Pile indicates a potential improvement of $30 \%$ in the front face neutron dose rates.

At the request of Operational Physics, Equipment Development is considering the use of Iron-serpentine concrete or Lron-polyethylene shielding rings in conjunction with the over-bore test at C Reactor.

A neutron detector facility was installed in the F Reactor top shield during September and is now in operation.

\section{Reactor Fundamentals Training}

The Fall serles of classes were started for P1le Operators and Reactor Specialists respectively. The Specialists group given class training at this time is the "non-operating" group; 1.e., not assigned to normal control room operating duties on a specific shift.

The attendance of approximately two-thirds of those eligible is indicative of the nonroutine assigaments which these people have and the subsequent scheduling difficulties. Attendance at the P1le Operator classes, on the other hand has exceeded $90 \%$, and is near $100 \%$ if regular absences from work are not counted.

\section{DECLASSFFED}

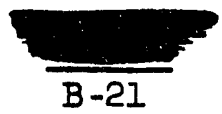


DR- I INOP

The DF-1 Loop was operated continuously during the report period with the exception of 90 hours during a reactor outage. Test reference conditions (1500F surface temperature) were maintained on the test element for 454 hours, bringing the total testing time to 1319 hours.

The No. I motor generator has continued to vibrate excessively under load conditions. It has been returned to the vendor for examination and repair. The vendor has agreed to replace the generator rotors. The new rotors will have stiffer shafts and improved electrical specifications."

An air compressor for back-up instrument alr supply to DR-1 has been installed and is belng tested before being placed in service.

Loop radiation monitors have indicited a gradual increase on successive reactor startups. Typically, the insrease is from about $15 \mathrm{mr} / \mathrm{hr}$ to 45 $\mathrm{mr} / \mathrm{hr}$. The total ilssion product concentration in the loop has remained below one curle, with xenon the only 1sotope identified to date.

\section{E-1 LOOP}

The H-I Loop was cooled by single-pass process water during the entire report period.

The No. 3 canned motor pump (Westinghouse Model 150-D) has been shipped to the Westinghouse MIR-EIR Site Operation at the National Reactor Testing Station.

\section{Sample Irradiations}

The following samples were irradiated or undergoing irradiation during the month.

\begin{tabular}{|c|c|c|c|c|c|}
\hline actor & $\begin{array}{l}\text { Test } \\
\text { Hole }\end{array}$ & Fac1l1ty & $\begin{array}{l}\text { Request } \\
\text { Number }\end{array}$ & $\begin{array}{l}\text { No. of } \\
\text { Samples }\end{array}$ & Material - Purpose \\
\hline $\begin{array}{c}D-D R, H \\
D R\end{array}$ & & $\begin{array}{l}\text { PCCF } \\
\text { PCCF }\end{array}$ & $\begin{array}{l}\text { BAPO } 184 \\
\text { BAPO } 172\end{array}$ & $\begin{array}{r}10 \\
6\end{array}$ & $\begin{array}{l}\text { Washington-deslgnated program } \\
\text { Effluent water (radiolsotopes } \\
\text { in effluent water study) }\end{array}$ \\
\hline KW & $4 B$ & Snout & HAPO, 172 & 6 & \\
\hline $\mathrm{DR}$ & & PCCF & BAPO 218 & 4 & $\begin{array}{l}\text { Natural uranium (fission } \\
\text { product release studies) }\end{array}$ \\
\hline$F$ & $\mathbf{E}$ & Quickie & HAPO 219 & 3 & $\begin{array}{l}\text { Strontium (separations plant } \\
\text { waste product study) }\end{array}$ \\
\hline $\begin{array}{l}F \\
F\end{array}$ & $\begin{array}{l}\mathbf{E} \\
\mathbf{E}\end{array}$ & $\begin{array}{l}\text { Quickie } \\
\text { Quickie }\end{array}$ & $\begin{array}{l}\text { HAPO } 227 \\
\text { HAPO } 229\end{array}$ & $\frac{1}{8}$ & $\begin{array}{l}\mathrm{UO}_{3} \text { (isotope production) } \\
\text { UO? (thin films) }\end{array}$ \\
\hline
\end{tabular}




\section{DECLASSFFED}

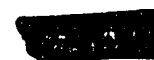

HW -66970

\begin{tabular}{|c|c|c|c|c|c|}
\hline Reactor & $\begin{array}{l}\text { Test } \\
\text { Hole }\end{array}$ & Facility & $\begin{array}{l}\text { Request } \\
\text { Number }\end{array}$ & $\begin{array}{l}\text { No. of } \\
\text { Samples }\end{array}$ & Material - Purpose \\
\hline $\begin{array}{l}\mathrm{DR} \\
\mathrm{KW}\end{array}$ & $4 \mathrm{C}$ & $\begin{array}{l}\text { Proc. tube } \\
\text { Snout }\end{array}$ & $\begin{array}{l}\text { HAPO } 215 \\
\text { EAPO } 242\end{array}$ & $\begin{array}{l}1 \\
1\end{array}$ & $\begin{array}{l}\mathrm{UO}_{2} \text { (ceramic fuels investigation) } \\
\text { Non-flssionable eutectic (PRIR } \\
\text { temperature detector test) }\end{array}$ \\
\hline $\mathrm{DR}$ & & PCCF & BAPO 223 & 1 & $\begin{array}{l}\text { Antimony-berylilum (neutron } \\
\text { source activation) }\end{array}$ \\
\hline $\begin{array}{l}\text { KW } \\
\mathrm{C}\end{array}$ & $\begin{array}{l}2 C \\
D\end{array}$ & $\begin{array}{l}\text { Hot graphite } \\
\text { Bore channel }\end{array}$ & $\begin{array}{l}\text { BAPO } 177 \\
\text { HAPO } 237\end{array}$ & $\frac{1}{2}$ & $\begin{array}{l}\text { Graphite (damage studies) } \\
\text { Inconel (PRIR Gas Loop material } \\
\text { study) }\end{array}$ \\
\hline $\begin{array}{l}K W \\
K E \\
K E \\
K E \\
K E\end{array}$ & $3 \mathrm{~A}$ & $\begin{array}{l}\text { General purp } \\
\text { Genma } \\
\text { Genma } \\
\text { Genma } \\
\text { Genma }\end{array}$ & . BAPO 236 & $\begin{array}{r}1 \\
12 \\
4 \\
8 \\
6\end{array}$ & $\begin{array}{l}\text { Zirconium (creep test) } \\
\text { Purex waste tank coverling materlal } \\
\text { NPR radiation alarm chambers } \\
\text { Grease and oli (damage studies) } \\
\text { Glass (damage studies) }\end{array}$ \\
\hline
\end{tabular}

Borescoping Activities

Process Channel 4163, 105-H - A graphite block has been dislocated and obstructs one-fourth inch of the inlet tube sleeve opening.

Process Tube 3865, 105-D (RIbbed Z1rcontum Tube) - The tube appeared to be in good condition although heavily coated with film.

Process Tube 4364, 105-D - The top of the tube had been gouged.

Process Tubes 4158, 4160, and 4188, 105-D - These tubes appeared to be in good condition (they were examined because of a reluctant fuel charge movement).

Vertical Bowling Measurements

A summary of the results of vertical bowlng measurements taken in process tubes follows. All distances are measured from the process tube inlet flange. Reactor Date Number Distance Remarks

H 9-8-60 $\quad 4674 \quad 36$ feet Down .03 inches at 8 feet since 4-20-60.

Down .19 inch at 23 feet since 4-20-60

COOLANT TIESTING OPERATION

KER Loop Operations

$\frac{\text { KFR-1 }}{\text { month. }}$ - The loop was on single-pass operation with dumiles throughout the

$\frac{\text { KER-2 - The loop was on single-pass operation with dumies throughout the }}{\text { month. }}$

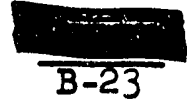


KMR-3 - Testing, as described and authorized by PT-IP-309-A and PT-IP-309-A, Supplement A, of a Zircaloy-2 fretting corrosion sample and NPR-type fuel elements and the irradiation of defected fuel elements for fallure testing in $278 \mathrm{C}$, pH 10 water continued throughout the month.

On September 9, 1960, a severe leak developed on a front face connector fitting. The loop temperature and pressure were decreased at emergency rates without any noticeable change in the leak rate. The reactor was manually shut down to prevent any damage which might result from a complete tubing break.

The derective fltting was replaced. An examination of the fitting revealed four longitudinal cracks in the tubing sleeve. A detalled radiometallurgical examination is underway.

KFR-4 - Testing of tube-and-tube fuel elements with "hot-headed" end closures on the Inner tubes and the normal welded closures on the outer tubes, as authorized by PI-IP-300-A. Testing is to evaluate the behavior of tubular fuel elements w1th "hot-headed" end closures during irradiation in $288 \mathrm{c}$, $\mathrm{pH} 10$ water.

On September 12, 1960, a leak developed in the main loop piping about four Inches downstrean of the junction of the primary heat exchanger exit and bypass lines. The loop pressure and temperature were reduced and the leak examined. The defect was a clrcumferential crack about one-half inch long. It was decided to leave the loop on reclrculation at reduced pressure and temperature unt1l the next reactor outage.

\section{6-KE Single-Pass Tube Operation}

Corrosion and effluent activity testing, as authorized by PT-IP-197-A, Supplements B and C, continued in two central-zone tubes supplied by 1706-KE high-head pumps. The tubes operated under the followling conditions:

$\begin{array}{llll}\text { Tube } & \text { 표 } & \text { Water } & \text { Dichromate } \\ 4355 & 7.0 & \text { F1ltered } & 1 \text { ppm } \\ 4456 & 7.0 & \text { F1ltered } & 1 \text { ppm }\end{array}$

\section{Outage Performance}

There was one unscheduled reactor outage charged to coolant Testing during the month:

$$
\text { September 9, } 1960 \quad \text { Front header leak on KRR-3 }
$$

A total of 11.4 outage hours was charged to Coolant Testing as Iisted below:

Production Test Description Time

IP-309-A

Front header leak on KER-3 $\quad 11.4$

IP-309-A, Supplement A 


\section{DECLASSFFIED}

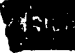

HW -66970

Ex-Reactor Facility Operation

1706-KE Mock-Up Tubes - The Iollowlng tests were continued throughout the month:

1. Corrosion characterlstics of aluminum cermets.

2. Corrosion characteristics of nlckel-plated fuel elements.

EIMO-4 - One rupture test serles was begun during the month.

ElMO-5 - Testing of Zircaloy-2, Haynes Alloy No. 41, Hasteloy-B, and carbon steel subjected to various heat treatments to determine the unfform corrosion in $290 \mathrm{C}$ and $\mathrm{pH} 10$ water was continued during the month.

ELMO-7 - Fretting corrosion tests on single-rod, PRIR-type fuel was continued during the month. The thermal cyclic tests on the Flodar tube fitting were completed.

ELMO-10 - Fifteen tests on low-temperature decontaminant scanning were completed during the month.

CEP-2 - Testing of mechanically-vibrated, zircaloy-2 fretting corrosion samples in $300 \mathrm{C}$, pH 10 water was continued during the month.

CEP-4 - Three decontamination cycles to determine the effects of a deoxygenated system on corrosion of stainless to carbon steel welds were completed. The decontaminants were AP-I and B1sulf-I.

Dowtherm - The heat transfer tests were started to determine the heat transfer coefficient change with time.

\section{COMPONEANT THSTING OPERATION}

Irradiated Material Bxamination

Examinations were completed on the fuel elements from the following thirtythree tubes at the Metal Examination Facility (105-c).

\begin{tabular}{|c|c|c|c|c|c|c|c|}
\hline$\frac{\text { PT No. }}{216 \mathrm{~A}}$ & $\frac{\text { Tube No. }}{2888-K T}$ & $\frac{\text { PT No. }}{216 \mathrm{~A}}$ & $\frac{\text { Tube No. }}{3177-7}$ & PT No. & & PT No. & Tube No. \\
\hline & $\begin{array}{l}2373-K E \\
4657-K E \\
3278-K E \\
3153-K E \\
2483-K E \\
4976-K E \\
4456-K E \\
0670-H\end{array}$ & & $\begin{array}{l}3257-\mathrm{H} \\
2561-\mathrm{H} \\
2778-\mathrm{H} \\
0675-\mathrm{H} \\
3768-\mathrm{F} \\
1291-\mathrm{F} \\
0384-\mathrm{F}\end{array}$ & & $\begin{array}{l}0750-\mathrm{KW} \\
4586-\mathrm{KW} \\
5484-\mathrm{KW} \\
5476-\mathrm{KW} \\
0748-\mathrm{KW} \\
1873-\mathrm{DR} \\
2658-\mathrm{DR}\end{array}$ & $272 A$ & $\begin{array}{l}3561-c \\
3570-c \\
3575-c \\
3675-c \\
3676-C \\
2264-c \\
3873-c \\
1069-c\end{array}$ \\
\hline
\end{tabular}




\section{DECLSSIFIED}

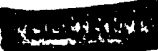

HW -66970

\section{Equiprent Development}

A new positioner was designed and installed in the optical profllometer. This positioner replaces the former device which wes incurring frequent breakdowns and causing a considerable reduction of profilometer avallab1lity.

\section{Process Tube Corrosion Monttoring Program}

In-reactor measurements of 549 process tubes were completed during the month. Listed below are the number of tubes measured per reactor and document numbers of reports issued.

$\begin{array}{ccccc}\text { Reactor } & \text { No. of Tubes Probologged } & \text { Report No. } & \text { HW Number } \\ \text { B } & 86 & & 45 & 66626 \\ \text { F } & 62 & 46 & 66691 \\ \text { H } & 24 & 47 & 66743 \\ \text { DR } & 244 & 48 & 66782 \\ \text { D } & 100 & 49 & 66797 \\ \text { B } & 33 & 50 & 66832\end{array}$

V1sual examination, wall thickness and $\mathrm{rib}$ height measurements were completed on one tube from B Reactor, two tubes from I Reactor, and one tube from KW Reactor.

Tube 3370-B was a ribless aluminum tube. The corrosion in the tube was very unfform. There was no evidence of ledglng-type corrosion or hot spot areas caused by warped or misaligned slugs. No scratches caused by the supports on the slugs were noticed in the tube.

Tubes 1975-H and 2075-H were removed because they were leakers. In tube 1975-H three transverse cracks were found on the top wall, located approximately 20-1/2 feet from the rear. The leak in Tube 2075-H was found approximately 11 feet from the rear Vanstone flange, located on the top half. The leak resulted from a combination of internal corrosion and the start of a transverse crack.

Tube 1446-KW was removed because of suspected damage in the front portion due to chattering of the seating charge. This portion of the tube could not be split for examination because it was too severelJ damaged.

\section{Panellit Programs}

Gages repaired and callbrated by maintenance personnel during the month totaled 379. Of this number, 63 gages were rejected for fallure to meet inspection criteria for a rejection rate of 16.6 per cent. The August rejection rate was 34 per cent. 


\section{DECLSSSFFED}

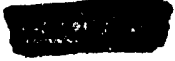

$\mathrm{HW}-66970$

In-board reliability examinations were performed on 1183 gages. A total of 111 were found to be sub-standard and were removed from service. This is a rejection rate of 9.4 , approximately f1ve per cent below the yearly average and 1.5 per cent below the August rate.

Response times were determined on a total of 1183 gages during the month. of this number, 11 gages showed slow response and recelved corrective action. This amounts to a 0.9 per cent slow response. Response time determination activities continue to show Improved gage response times. S1guflicant progress is shown by monthly performance percentages below:

$\begin{array}{lc}\text { November, } 1959 & 12.0 \text { (start of program) } \\ \text { December, 1959 } & 9.5 \\ \text { January, 1960 } & 12.5 \\ \text { February, 1960 } & 7.5 \\ \text { March, 1960 } & 4.8 \\ \text { Apr1l, 1960 } & 4.85 \\ \text { May, 1960 } & 2.7 \\ \text { June, 1960 } & 3.6 \\ \text { July, 1960 } & 3.8 \\ \text { August, 1960 } & 1.2 \\ \text { Th1s month } & 0.9\end{array}$

In-board Bourdon coll leak examination of 2145 gages during the month resulted in detection of 11 leaking colls. This constitutes a leak failure incldence rate of 0.51 per cent, virtually equal to the average rate of 0.46 per cent which has been experlenced during the past two years.

"Critical component" Inspection of Panellit gage components, for warehousing and direct-to-user availability, was as follows:

Switches Bourdon Colls

$\begin{array}{lcl}\text { Inspected } & 143 & 0 \\ \text { Rejected } & 35 & 0 \\ \text { Rejection rate } & 24.5 \text { per cent } & 0\end{array}$

Rejection rate of switches was considerably higher than last month's rate but approximately normal for the past year's switch-inspection activities. During the month, 92 gages recelved routine failure analysis program
attention.

During the month accelerated corrosion testing of dial pivots treated by an "electro-filming of graphite" process, was terminated. Also, a new series of tests was started on a new plvot material identifled as Armco, Type 17-4 pH stainless steel. Results of the electro-filmed pivot tests were quite satisfactory in that extremely small quantities of corrosion resulted. 
PRODUCTION, ENGINHFRTING \& REACTOR OPERATIONS

PRODUCTION OPERATION

PRODUCTION PLANNING \& SCHEHDULING OPERATION

DECLASSFFIED

There were no discharge exposure adjustments effected in September. Metal performance was excellent (only three ruptures were incurred) resulting in an improvement in discharge exposures to the bighest level of this calendar year.

Discharge Exposure Comparison (MWD/T)

\begin{tabular}{|c|c|c|c|c|c|c|}
\hline & Regul & Solid & Regule & $I \& E$ & Enrich & $I \& E$ \\
\hline & $601 d$ & $2 x^{\prime} s$ & $601 d$ & $2 K^{\prime} s$ & 6 old & $2 K^{\prime} 3$ \\
\hline $\begin{array}{l}\text { July } \\
\text { August } \\
\text { September }\end{array}$ & $\begin{array}{l}671 \\
711 \\
697\end{array}$ & $\begin{array}{l}776 \\
588 \\
745\end{array}$ & $\begin{array}{l}659 \\
686 \\
687\end{array}$ & $\begin{array}{l}691 \\
684 \\
706\end{array}$ & $\begin{array}{l}778 \\
788 \\
842\end{array}$ & $\begin{array}{l}762 \\
690 \\
720\end{array}$ \\
\hline
\end{tabular}

\section{ESSENTIAL MATERIAIS}

Rail and truck shlpments received in September were as follows:

Carload shipments for IPD $\quad 163$

Carload shipments for other Depts. $\quad 142$

Truck shipments for IPD 223

Total 528

\section{MISCEMIANEOUS ACTIVITIES}

W. H. Coleman, Fleld Consultant for the Mfg. Training Program Irom Ft. Wayne, Indiana, visited HAPO September 19 through 23. His consultation time here was administered to the best overall advantage of all departments participating in the MITP.

The first four classes of Pile Operators were started in the new 1thour course of supplementary training in reactor fundamentals. This course, like the similar ones for Reactor Speciallsts and Utility Operators, is being instructed by the Operational Physics Operation.

The class in the new Fundamentals of Manufacturing course started in March resumed its sessions on September 6 following a summer break. Feedback from the spring sessions led to some revision of the remaining lessons, and an overall shortenting from 56 to 51 sessions.

Arrangements were made with the Relations Operation for IPD Instructors in "Fundamentals of Manufacturing" and $N$ Reactor trainting to be included in the Instructor Training Workshop to be conducted at Hanford by Genera? Electric Manufacturing Services specialists on October 3-4.

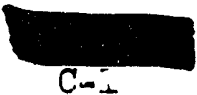




\section{$+4$}

HW- 66970

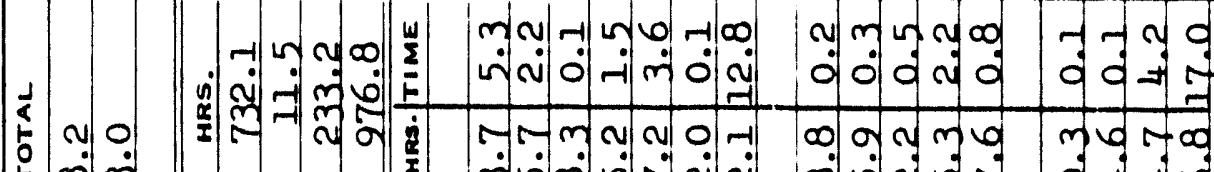

1

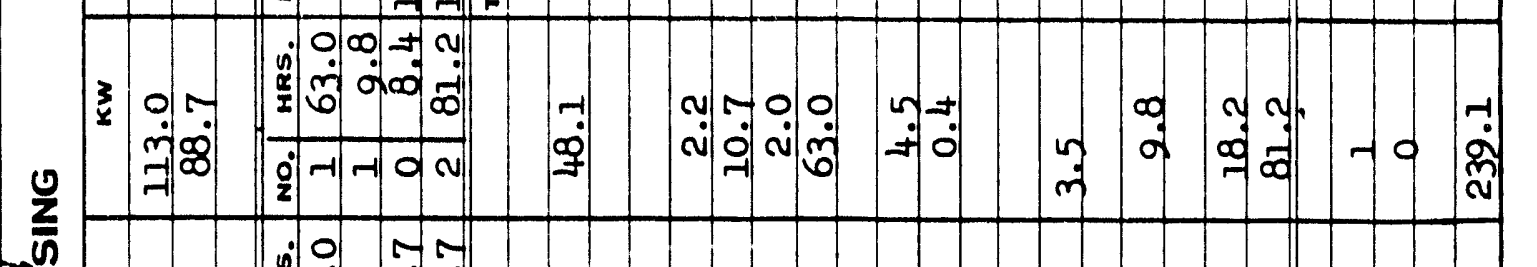

8

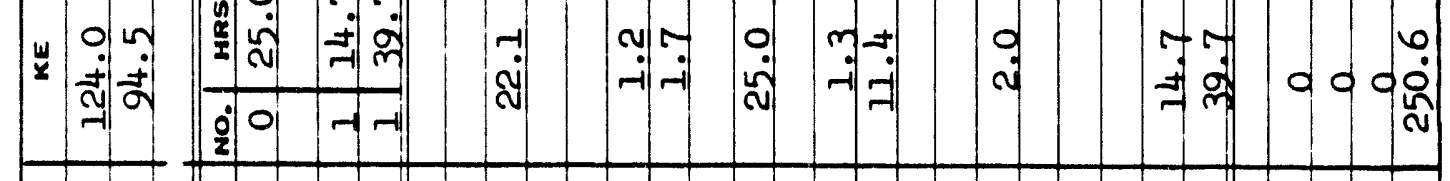

a

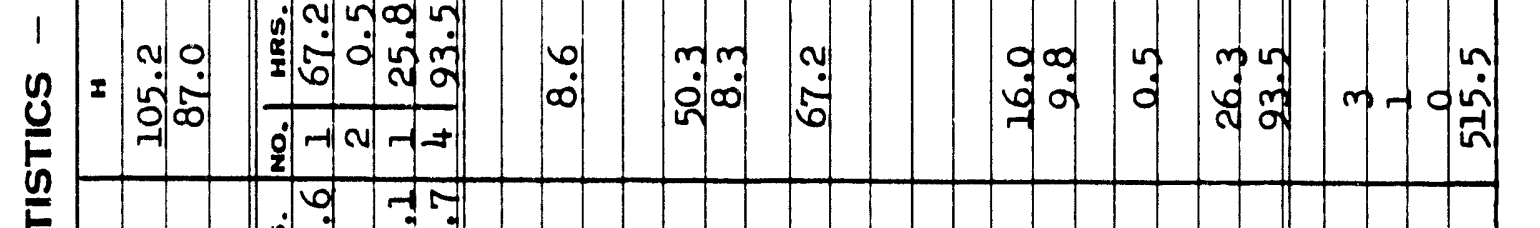

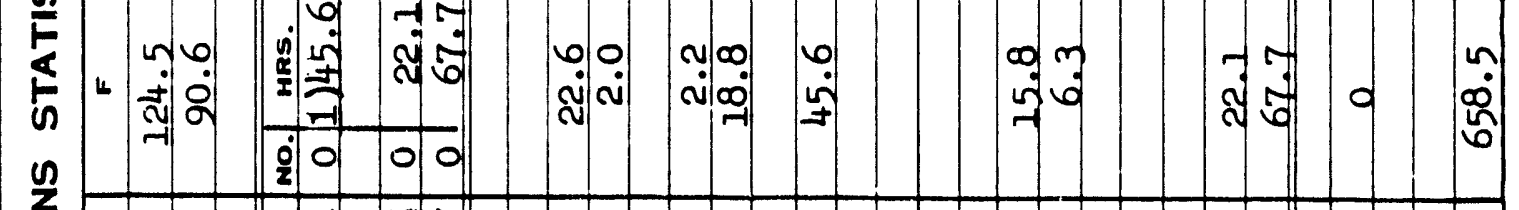

(

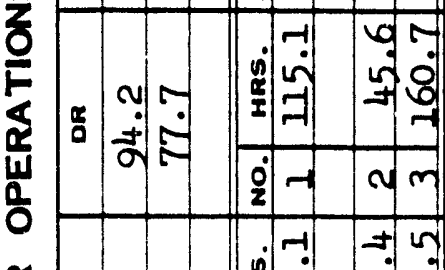

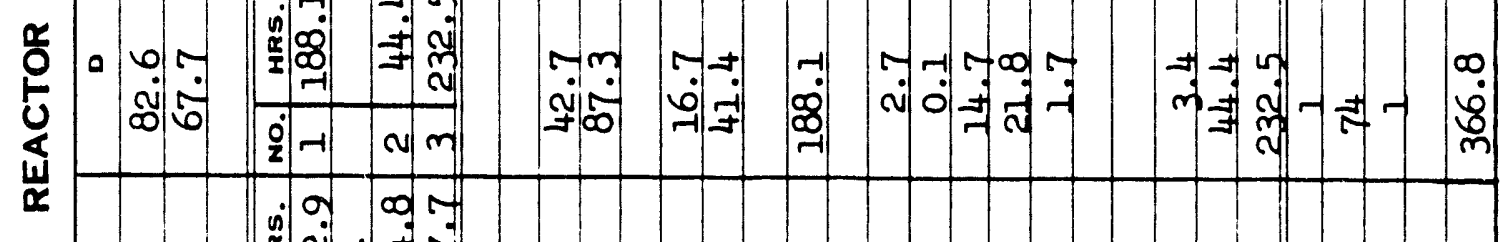

0 에

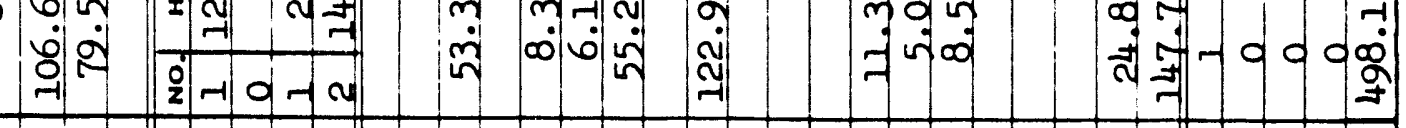

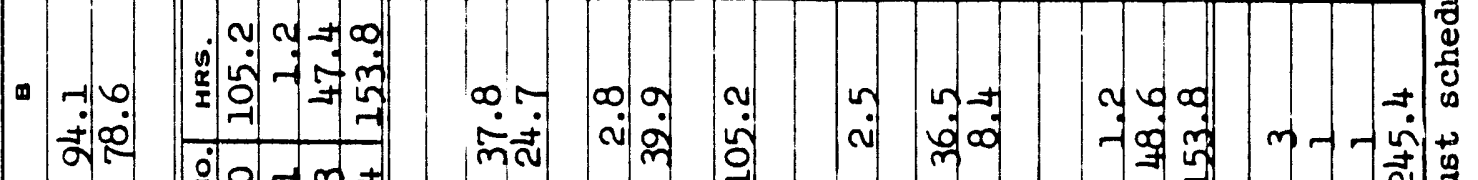

वี

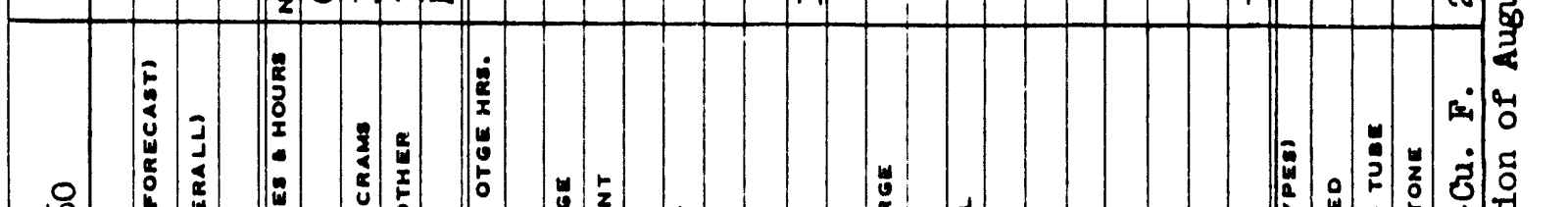



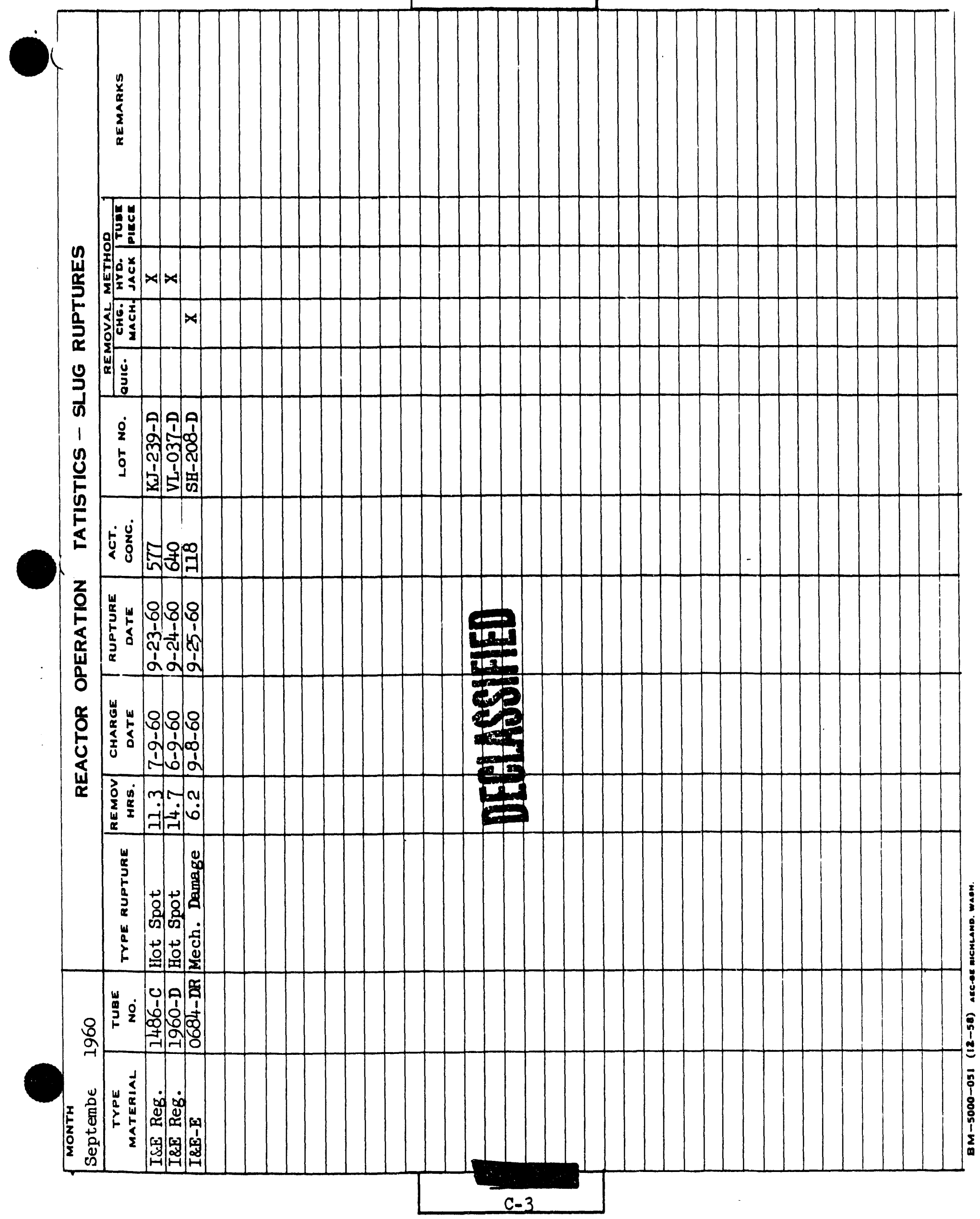


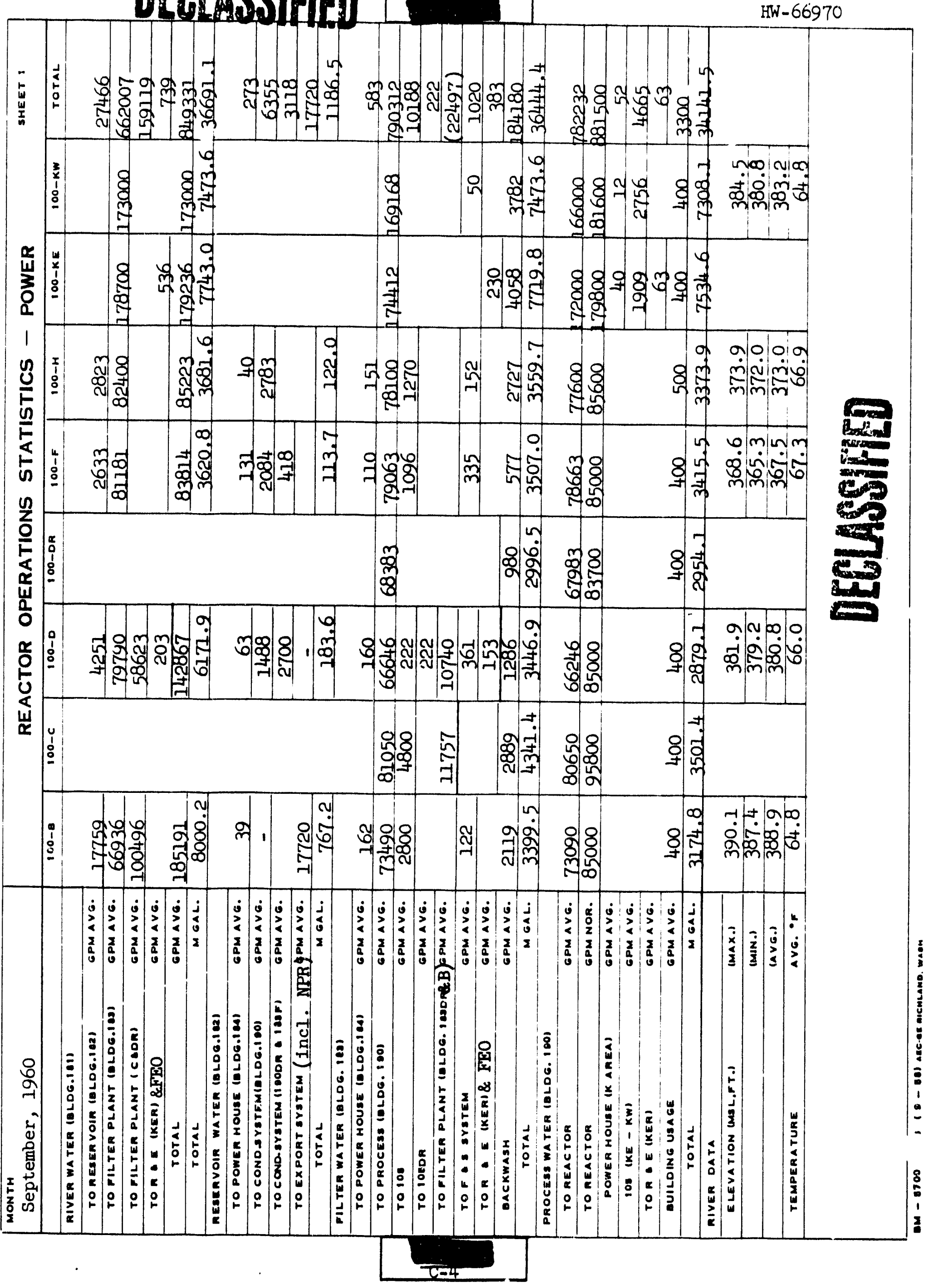




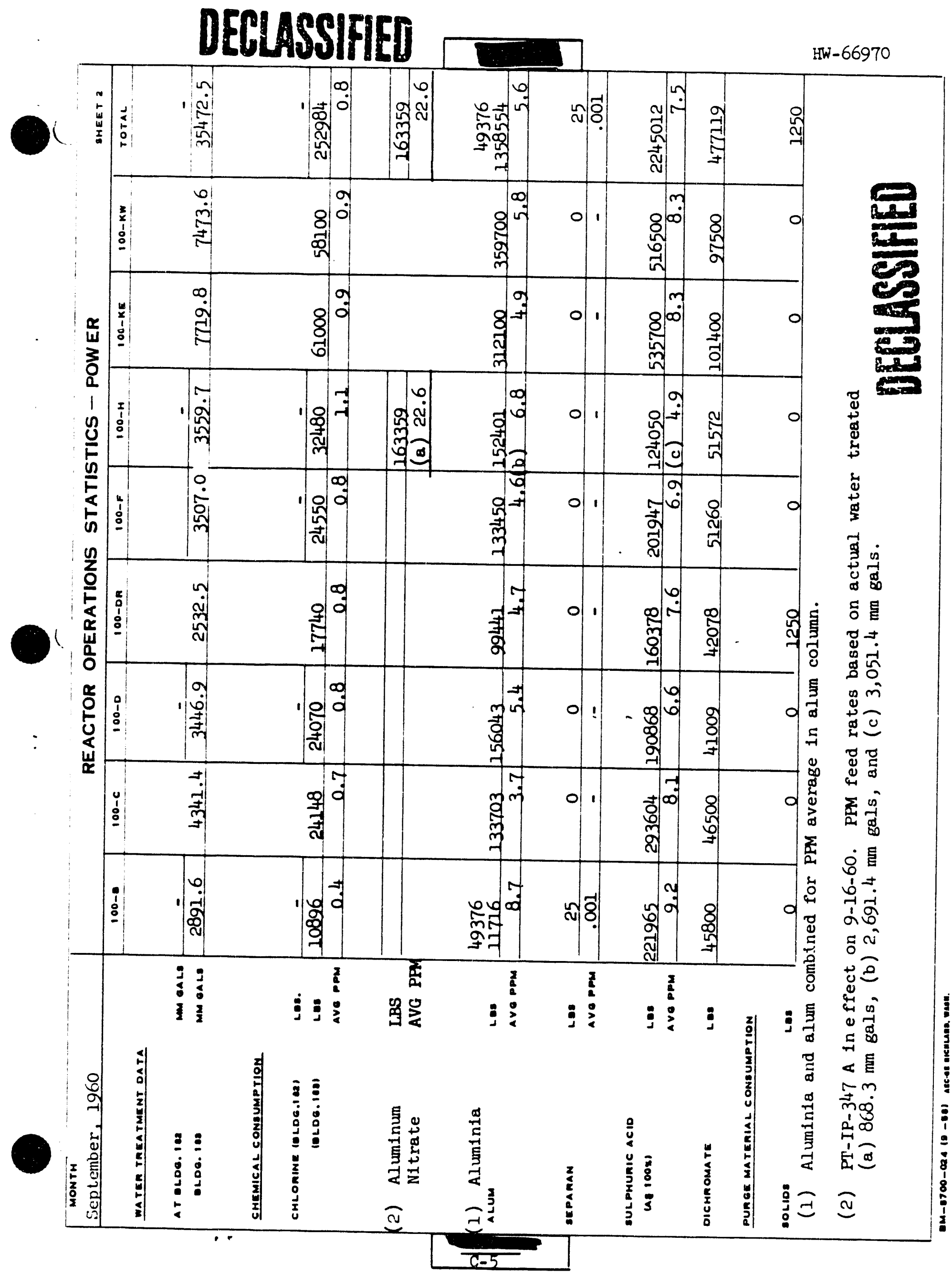




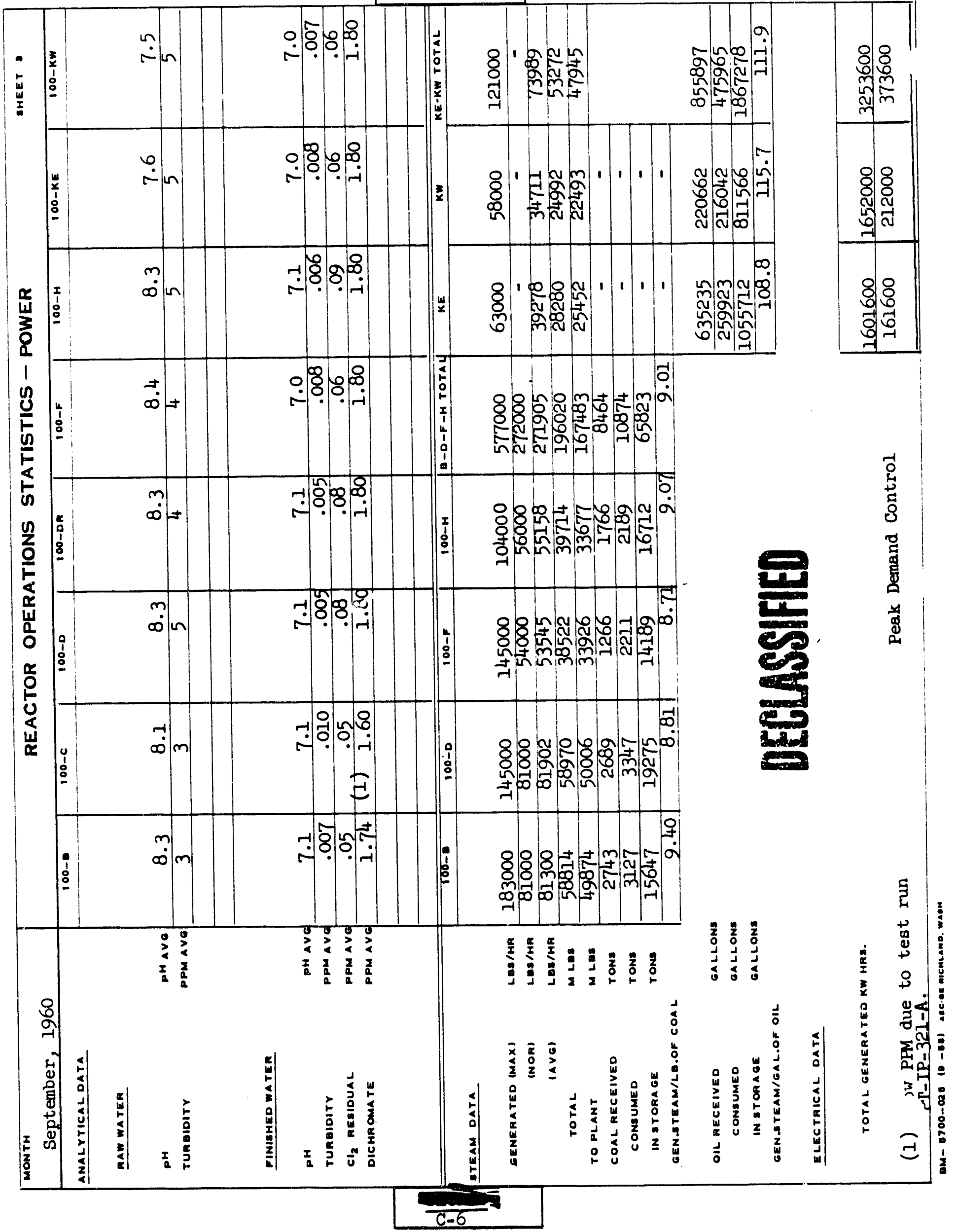


APPIIED REACTOR ENGINEERING OFERATION

INDUSTRIAL ENGINAERING OPERATION

Program of Charge-Discharge Improvements

A program of charge-discharge improvement in the six older reactors was defined in June, 1959, and has been followed since then. Methods and time standards have been developed for all charge-discharge activity.

The procedure for charge-discharge using ram type charge seaters has been completed and is scheduled for performance test at 105-F building. The F Processing Operation will administer the test of the procedures with the aid of Industrial Engineoring Operation personnel.

Prepare Training Films

A training film on rear face cap handling techntques has been prepared for presentation to Processing exempt and non-exempt persomel in $B, C, D, H$ and $F$ areas. The film has a running time of approximately $10 \mathrm{l} / 2$ minutes.

Reactor Outage Reporting Procecure

An investigation is being made to devise a standard procedure for reporting outage time in all eight reactors. A recommended revision of the 105-D, DR Outage Reporting Procedure has been completed and distributed to interested personnel for their comments.

Methods Appreciation Courise

The first three presentations of a four-hour, two session training course have been made to Manufacturing Supervisors and Specialists. It is expected the meetings on this subject will be completed for Processing personnel by mid-December, 1960.

Determination of the Base Painting Load in IPD

As requested by the Manager, H Reactor Operation, a five-year cyclic painting schecule is being prepared. This schedule is based on a visual inspection of buildings and installations to ascertain approximately what year they should be schoduled for palnting. Historical data is being used to estimate the required number of manhours and material requirements.

In addition, a comparative cost estimate is being made using a synthetic standard. From the amount and type of painting that is performed, the man-hours and materials are established using Ramond Time Standards. A painting cost estimate will be derived from these labor and material figures. Lead Reactor Installation, Fuel Element Material Handling, Work Area and
CElevator

Scope designs for lead reactor installation in 105-F Building are being prepared. Revisions are being made to eliminate high cost items from the
original estimate. 
Program for Improvements in Overboring Practice

Films taken of the overboring tests at $F$ Reactor are being used by Mechanical Development engineers to assist in the development of efficient overboring tools. Industrial Engineering personnel will film the overboring of 5 channels at the next 105-F tube outage. The purpose of the filming is to establish a permanent record of the task performance for use as development and training tools.

Optimum Inventory and Usage of Durmies

1 study is being made to consider the possibility of minimizing the types of dumies being used to cut the costs of these essential materials.

Rupture Methods and Time Standards

The establishment of a system of methods and time standards for removing rupture material has been suggested as a means to standardize and minimize the outage time used for this purpose. This study should reveal the best present methods and equipment, suggest new methods and equipment where improvements can be made, and provide times for the various tasks performed in the process of removing the rupture.

Radiation Monitoring Appreciation Course

At the request of the Processing Managers, a Radiation Monitoring Appreciation Course is being prepared for presentation to Processing exempt personnel. The objective of the course is to assist the Supervisors in guiding and training Radiation Monitors. Tentative planning indicates the course will be offered late December, 1960, or early January, 1961.

\section{MAINTENANCE PRACTICES ORERATION}

Spare Parts Inventory

The Irradiation Processing Department portion of the spare parts inventory was $\$ 1,750,647$ as of September 30,1960 . During the month, revisions to spare parts inventory were as follows:

\begin{tabular}{|c|c|}
\hline $\begin{array}{l}\text { Decrease } \\
\text { Increase } \\
\text { Plants } \\
\text { Projects }\end{array}$ & $\begin{array}{r}\$ 44,277 \\
3,735 \\
\end{array}$ \\
\hline ver-all decr & \\
\hline
\end{tabular}

Several single items accounted for a large dollar movement: $\$ 39,500$ increase for the third spare $4500 \mathrm{kP}$ stator, and $\$ 28,460$ decrease for Operational Charge-Discharge spare part disposition. 
Maintenance Practices Operation is arranging for either rework or adjustment of 400 rear nozzle caps. These Stores items were found to be defective and negotiations are in progress to have corrections made, either by vendor or on-plant.

Helium Loss Reduction

A study is in progress to review the entire helium loss problem and develop recommendations for reducing losses. This includes review of system components and system operation, recommending improved operation procedures for unloading, addition, and purging, and methods of leak detection and leak correction. Initial work disclosed the feasibility of installing a gas purification and/or a rear face sealing system to permit reactor operation at minimum gas pressure. An engineering request is being prepared to request Facilities Engineering Operation to perform an engineering scope of this concept.

\section{Personnel Elevator}

A study was made of the 105-C metal loading elevator to determine if this equipment could be adapted to carry personnel. The increased use of splines and the attendant increase in personnel traffic to and from the elevator, indicated a need for a personnel elevator. The report recomended that the extensive modifications that would be required, both by elevator code and engineering, did not economically warrant revising the elevator. The most practical and economical solution would be to provide a new elevator for personnel service.

\section{Front Face Piping and Fitting Study}

The Front Face Piping and Fitting Study, which recommended improved front face hardware as a necessary step toward the return to the Dry Front Face Criteria, has been forwarded to Facilities Engineering Operation for action.

Reactor Tool Standardization

A study is in progress to investigate maintenance tool utilization at the various areas; primarily, reactor and outage tooling. The objective is to scope the problem and develop recomendations to standardize maintenance tools and equipment.

\section{Third Party Inspection}

One boiler, six pressure vessels, and one rear elevator were inspected by a representative of the Travelers Insurance Company during September.

Tube Replacement Problems

A study is in progress on the problem of pulling in replacement process tubes. Recent tube replacement outages indicate a problem area trend, difficulty in pulling in replacement process tubes and increased numbers of tubes which cannot be pulled completely into the reactor. This problem ties in with the graphite distortion and resultant short radius graphite 
channels, relative inflexibility of the tube pulling mandril, and the friction of the process tube at the points of sharp graphite radius. It is probable that new tool development is required to achieve tooling which will perform chamel straightening to correct two problems; tube pull-in, and tube damage from graphite abrasion.

\section{HP Motor Rewind Program - 190 Annex Buildings}

Maintenance Practices Operation and Facilities Engineering Operation are collaborating on the $4500 \mathrm{HP}$ stator replacement schedule to coordinate the plant work and vendor service shop work. Data has been collected and presented to management for decision in the location of select stators by correlating purming plant capacities and reactor capabilities.

Maintenance Practices Operation initiated action with the vendor to assure that a vendor strike would not tie up coils and stator now at vendor's plant.

\section{Service Manuals}

The instrument service manual covering Project CG-791, was completed and distributed to engineers, supervisors, and instrument personnel.

Electrical service manuals on the reactor safety circuit and horizontal control rod systems are being propared.

Instrument Evaluation

Four radiation monitoring systems are currently being evaluated by Maintenance Practices Operation's Instrument Engineer for the purpose of selecting a possible replacement for the obsolete equipment now in use. Two of the systems are HAPO developed, and two are vendor designed systems.

\section{Standard Servicing Procedures}

The inventory of all installed process instruments in Irradiation Processing Department is completed. The inventory is the first step in acquiring data necessary to formulate standard instrument service and procedures.

\section{Craft Training}

Malntenance craft training was provided on the following items:

Mechanical Craft

Nozzle Hardware: Two 6-hour training sessions were attended by 29 mechanical maintenance personnel.

Flexible Front Face Connectors: Two 2-hour training sessions were attended by 24 mechanical maintenance personnel. 
Tool Balancer: One 2-hour training session was attended by 25 mechanical maintenance personnel.

Powder Actuated Tools: A 2-hour training session was given 6 mechanical personnel.

Instrument Craft

Theory and Application of Automatic Controls: Nine 4-hour training sessions were attended by 6 instrument trainees.

\section{Safety Specialists' Activities}

A formal investigation was held September 9, 1960, of the incident involving the J.A. Jones Company personnel who were working in the downcomer of the 105-B Building. The accident was caused by inadequate ventilation, which resulted in heat exhaustion of two employees.

The Safety Specialists participated in reviewing plans for remodeling sections of the 1706-KE Building.

The Golden Shoe Award pins and certificates were presented to three employees of 100-D, DR Reactor Operation.

Material was procured and distributed throughout Irradiation Processing Department for Fire Prevention Month activities.

PLANT EQUIFMENT ENGINGERING OFERATION

Bumper Fuel Element Program

Modified nozzles were installed as schechled on D Reactor to support Production Test I-262-A-II-FP, "Evaluation of Projection Fuel Elements for Use in Ribbed Process Tubes". Approximately 20 of the scheduled 100 tubes were charged with bumper elements. Difficulties encountered with fuel-process tube interference resulted in charging machine failure. 


\section{$\mathrm{HW}-66970$}

\section{B-C REACTOR OPERATION}

\section{OPERATING EXPERIEITCE}

\section{DECLASSFFED}

Power level was limited at B Reactor in consideration of tube power and at C Reactor for control of rupture potential. Production was intermpted at $B$ Reactor for repair of water leaks, both internal and external, and at C Reactor for removal of a ruptured fuel element.

\section{EQUIPMEATT EXPFHR IEHTCE}

Subsequent to modifications for increased flow capacity of the B Reactor dowacomer, pressurization of the 105-B effluent water junction box and a resultant perlodic discharge of water from the far rear riser vent has been experienced. Facilities Ingineering Operation is studylng this problem.

Three leaking process tubes were replaced at B Reactor. Gas leakage from flve front gunbarrel bellows was stopped by injections of slilicone foam. Three displaced mattress plates were reinstalled in the 105-B discharize chute liner; new holding clamps are being fabricated to eliminate plate movement as a result of slug impact.

An increase in the number of leaking, rear face nozzle connectors at $C$ Reactor was partially corrected by installation of a modifled elbow at each of 281 connectors; the modifled elbows employ double-"O" rings to seal nozzle connections.

Burned-out chamber drive motors were replaced at G- and H-hole chambers of the $C$ Reactor low level neutron monitor system.

Replacement impellers, with wear rings welded to their hubs were installed in the pumps of $\mathbb{N o}$. 2-C and $\mathbb{O} 0$. 4-C process pumping units at Building 190-C; worn impeller assemblies were shipped to Ios Angeles for rebuilding by the vendor, Byron Jackson Pump Company. No. 11-C pump was subjected to a capacity test to determine actual performance of the third-generation impelier installed in July, 1960. Test data indicated actual pumping capacity to be insignificantly less than specified in design criteria.

\section{TMPROVEMEENT EXXPER IFHTCE}

New bayonet-type inserts being tested as shields at vacant tube channels apparently reduce the front-face neutron levels at $B$ Reactor by a factor of 1.8 .

A conveyor was installed on the $D$ elevator at $B$ Reactor to speed the handling of rear nozzle caps.

Alum feed was increased from the average $6.8-7.2 \mathrm{ppm}$ to $20 \mathrm{ppm}$ on a halfplant besis at 183-B in conjunction with initiation of Development Test No. IP-357-A. HW-66736 describes this water treatment study aimed at reduction of $\mathrm{P} 32$ in reactor effluent water. No adverse effects on reactor operation are apparent after two full weeks of test operation. 


\section{DECLASIFIED}

$\mathrm{HW}-66970$

A new material (hypalon) is belng tested at B Reactor as a sealant of fas leaking breaks in the neoprene seal.

In connection with vertical safety rod operating difficulties at $C$ Reactor, a traverse target has been deslgned to aid in inspection of the VSR channels; estimates of fabrication costs have been requested. Design work continued On a VSR channel drill and a jack for reseating displaced graphite blocks now partially obstructing the VSR channels.

Installation work continued on the Bauxite feeder system at Bullding 183-C with completion scheduled for early October.

Installation of replacement cables and conduit in the secondary electrical supply system to the 183-B pumping facllity was completed and the system returned to normal service.

The Columbia River monftoring system was completed during September; river level and water temperature at a point one mile downstream from Priest Raplds Dam is transmitted by telemetering equipment to continuous recorders at Building 183-B.

\section{RADIATION MONITORIYG EXPERIEMYCE}

Two Maintenance Operation employees, assigned to tube burlal, encountered dose rates of flve $\mathrm{r} / \mathrm{hr}$ as results of malfunction of a cask door opener. 
D-DR REACTOR OPERATION

OPERATING EXPERIENCE

Operating levels at both reactors were limlted by bulk outlet temperatures and non-equilibrium conditions. A scheduled outage at each was for tube replacement at $D$ and b.lock discharge at $D R$. Both reactors experienced a water leak and a rupture.

During the s seduled outage at D Reactor downcomer modiflcations and Ball $3 X$ revislons were made. Sleeved and overbored nozzles were installed for the bumper fuel element program and 12 columns charged with the bumper slugs.

\section{EQUIPMENT EXPERIENCE}

Two of the 73 tubes replaced at D Reactor were replaced twice because of damage from stuck charges caused by graphite distortion. Twenty-eight tubes were probe tested to determine the extent of the distortion.

Downcomer revisions at $D$ Reactor consisted of enlarging holes in trays and removal of down pipes which connected alternate trays. Crossover piping back pressures and downcomer venting problems are yet to be resolved.

A cracked motor shaft on the transfer area crane at DR kept the unit out of service for a week before replacement was made with a motor from a 200 North area crane.

Pump motors at 181-D and 190-DR were returned to service after coll fallure by removal of the damaged colls. Off-plant shipment for permanent repalr is scheduled.

\section{IMPROVEMENT EXXPERIIENCE}

PT-IP-262-A Bumper Fuel Elements - The final four columns of 1.47 per cent enriched material were discharged, demonstrating a factor of improvement of 38 over normal I \& E material at a confidence level of 95 per cent.

Improved Gas Analysis Iristrumentation - A gas chromatograph installation was completed in $115-D$ for use of $D$ Reactor. Inftial operation has been satisfactory and personnel are being trained in operation and maintenance of the system.

All of the $4500 \mathrm{hp}$ pump motors in the 190 bulldings have been equipped with open bus-bar type electrical connections in place of taped connections. The new equipment is expected to save 8 hours each time a motor is replaced or repalrs made by the coll cutting method.

\section{RADIATION MONTTORING EXPERIENCE}

No radiation overexposures occurred during the month.

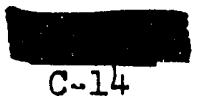




\section{DECLASSFFED -}

D Reactor had one and DR Reactor three lapses of radiation control during the month.

Surface dose rates inside the $D$ Reactor downcomer were reduced from 300 $\operatorname{mrads} / \mathrm{hr}$ to $40 \mathrm{mrads} / \mathrm{hr}$ by decontamination with Sulfam-1 solution, preparatory to the modification work. Venting problems, arising after the work, caused dose rates up to $13.5 \mathrm{rads} / \mathrm{hr} 10$ feet from a llapper valve in the vent line. Use of the near DR efiluent line for venting, as a corrective measure, caused background increase at $D R$ when vapors emitted from the $D R$ near downcomer vent. 
The operating level of the reactor was controlled by the bulk outlet temperature limits for the greater part of the month; the remainder of the time the level was controlled by tube power.

\section{EQUIFMENT EXPFERIEHNCE}

Sixty tubes were probologged, of which three were found to have severe corrosion requiring them to be removed from service. Two other tubes were also removed after they were determined to be leakers.

Seven 190 pumps and motors were in service at start-up on September 3. The elghth unft was placed in service on September 7, during reactor operation, after a damaged coll in the No. 5 motor was bypassed.

Work was continued on restorling the reactor zone temperature system and included replacement of 11 resistance temperature detectors. Three faulty reactor thermocouples were repalred, however, 13 additional failures occurred during the month. Other instrumentation activity included replacement of 31 Panellit gages.

An 1nvestigation of the 60-inch effluent line established that the pipe was moving through the concrete anchor. Measurements indicate the line has crept approximately one-half inch in the last two months. A method of correcting this condition has been developed which should prevent potential damage to the 107-F basin inlet.

\section{IMPROVEMENT EXPERTENCE}

The 105-F high tanks' discharge lines were descaled on September I with an inhibited sulphurlc acid solution, and drawdown tests demonstrated a 20 per cent improvernent in water flow resulting from this operation.

The bulk chlorine feed facllity was completed and placed in service on September 8.

A rubber sealing agent and rejuvenator was applied to approximately 63 per cent of the rear face neoprene seals to reduce reactor gas losses.

Points 5 and 6 of the new temperature deviation recorder are currently being used to print outlet water temperatures. This permits the reactor operator to know the bulk outlet temperature at all times.

Design Change No. 368-F, "Ball 3X Extra Low Pressure Switches," was completed.

A new type weatherproof cord cap was installed on each of the reactor building storage area hoists to reduce water damage. 


\section{DECLASSFFED}

HW -66970

A 1750 watt, 220 volt duratest mercury arc 11 ght was 1nstalled for underwater lighting test purposes in the storage basin.

\section{RADIATION MONITORING EXPERIHHCE}

Three lapses of radiation control were oustalned during the month. No exposures above applicable wo ling limt ts were involved. Three cases of personal contamination up to $4,000 \mathrm{c} / \mathrm{m}$ were incurred during spline removal operations. All were readily reduced.

\section{DECLASSFIED}


Equilibrium power levels reached $1675 \mathrm{MW}$. Bulk outlet effluent water temperature prevented further increases.

The reactor was shut down on september 6, to permit descaling of the high tanks in order to 1mprove the1r water flow characterlstics.

\section{EQUIPMENT EXPER IFHNCE}

Twenty-four process tubes were probologged to determine wall thickness. All of the tubes were acceptable for continued service. A total of 665 tubes have been probologged to date, of which 495 were second-generation tubes.

Production Test IP-347-A, "Use of Aluminum N1trate in Place of Aluminum Sulphate for Water Treatment," was started on the west half of the II f1lter plant on September 16, with a feed rate of $12 \mathrm{ppm}$. The aluminum nitrate feed rate was gradualiy increased unt1l september 2l, when a feed rate of $28 \mathrm{ppm}$ was attajned, a rate sufficlent to control pH to 7.0 w1thout supplemental acid.leed. No difficulties have arisen to date with the aluminum nttrate feed; however, the fllterling rates on this slde of the plant were relatively low $(4.5 \mathrm{gmm} / \mathrm{sq}$. ft. $)$.

A new type broach (approxdmately 18 inches longer than the present broaches) was used on three channels to allerlate the tube insertion problems. Based upon the inftial success of the broach, additional testing in its use will be conducted during the planned tube removal and replacement during the October scheduled outage.

\section{IMPROVEMENT EXPPERIENCE}

An experimental 750 watt "Fluormerlc" lamp is being used for underwater lighting at the metal pick-up chutes. The results of one month's operation were so encouraging that four additional units have been requested.

The length of the downstream dunny pattern was increased by elght inches. This revision moves the active zone upstream by elght inches, which better centers the flux in the rod pattern and results in better rod control.

\section{RADIATION MONITORING EXPYRIEANCE}

Durling the month, there were no lapses of radiation control or radiation occurrences.

\section{CENTRAL MAINTEMTANCE}

Descaling of the high tanks at $\mathrm{H}$ Resctor was successfully concluded during the first week of the month. Total initial flow was increased 1,100 gpm -. from 10,800 to $11,900 \mathrm{spm}$. 
Power levels of the reactors were limited by the rupture control point with the exception of two dars at $\mathrm{KW}$ Reactor when graphite temperatures were the limiting factor.

A time operated efriciency of 94.5 per cent was the major factor contributing to the production record for a 30-das month achieved by KE Reactor. The one KE Reactor outage was caused by a steam leak in KIR Loop 3 at a flared joint near the expansion loop thermocouple block on the front face of the reactor. The leak was caused by stress corrosion cracking of the tube sleeve due to stress corrosion.

\section{ECUIPMENT EXPERTTENCE}

The Number I generator at 165-ks was temporarily removed from service when abnormal oscilizations of excitation were detected. The cause was determined to be poor commutation on the pilot exciter due to insufficient brush pressure. Replacement of the brush springs corrected the oscillation problein. Plans were made to examine the brushes of the other generators.

Storage tanks, pumps, heat exchangers, piping and unloading platforms of the caustic and silicate chemical feed sysiems no longer in use at 100-K were removed in preparation for transfer to $100-\mathrm{N}$.

\section{TMPROVEMANT EXPPERTINCE}

The second low lift pump motor to be rewound for 1500 H.P. capacity was installed in the Number 2 low lift pump at 165-KE. The motor was placed in operation at the present purm load capacity of 900 H.P. pending the installation of a larger capacity pump unit for increased coolant water flows.

The performance and maneuverability of the charge seaters was improved by changes to the air control system and elimination of unnecessary valves and piping. As a result, tho seating of newly charged metal columns was made safer and more positive.

\section{RADIATION EXPERTEMCE}

A defective seal permitted drainage of water that served as a radiation shield for irradiated poison splines in the "C" elevator pit. As a result, nine operators of a charging crew on the elevator received higher than planned radiation exposures. An investigation was held and steps were taken to prevent recurrence.

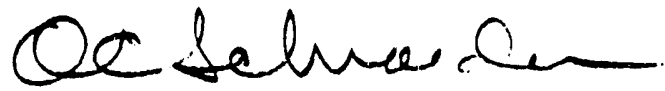

Manager

Manufacturing Operation

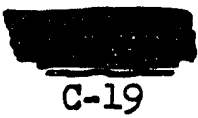




\section{FACIIITITS ENGINHHRRIVG OPERATION}

REACTOR MODIFICATTON DESIGN

RESEARCH AND DEVELOPMEMVT?

\section{DECLASSFIED}

Administration of the downcomer model testing program at Washington State University has been transferred to the Research and Engineering Operation. The transfer was made to shorten channels for colmunication with the Unt versity.

A design study is progressing to define the scope and modifications required to provide adequate coolant backup facilizities for three Reactor Modification Program cases: 1) a continulty of operation and safety case, 2) an expansion case, and 3) an Interim case. Details, including earthquake protection, are belng studied further.

A report has been recelved from Mr. G. R. Rich, Consulting Fngineer: following his evaluation of the export water system. H1s recomendations are : 1) that use of existing surge suppressors continue but that their operation be modified for pressure actuation rather than electrical actuation, 2) that additional slow-closing air valves be installed near the pump discharge manifold, and 3) that testing continue to determine the need for additional ais relief valves. Additional information has been requested from $\mathrm{Mr}$. Rich since his recomendations were not sufficiently detalled to permit design of the proposed modiflcations.

\section{DESIGAN PROJECTS}

CGI-791 - Reactor Confinement

Overall design is 99.5 percent, and detail design, 99.0 percent complete. Detall design extended past the target completion date of September 1 , due to the inability to obtain vendor information on the 105-K Reactor exhaust fan diesel drives. The design criteria for Phase III have been approved by the Project Representatives.

1

The testing program has been completed except for the Environmental Component Test $1 n g$ and the Development Tests for fleld checking the filter banks. Th1s latter test is to develop the procedure and equipment for fileld checieing the integrity of the filter banks after installation. The aerosol generators have been fabricated and are now being calibrated to measure the aerosol spectrum. The smoke photometer has arrived on site and is being callbrated.

CGI-839 - Modification of Fuel Element Test Facilities 1706-KKHR

Drawings for the KGR loop Iiner motor pumps have been returned unapproved to the vendor. . Several deviations from the original specifications were proposed. These are requiring extensive review. Objections were made to the vendor regarding the design of the electrical terminal lug for the 275 horsepower motor and for the method of installation of the pump heat barrier between the first stage impeller and the lower motor radial bearing housing since this design is contrary to pump specifications.

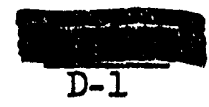




\section{DECLASSIFIER}

HW $-66,70$

The drawings and construction specification for the 1706-KER addition have been revised to include comments recelved from the Atomic Energy Comission. Both have now been approved and transmitted for contract preparation.

A design test has been Initiated to evaluate several nozzle-to-process tube and nozzle-to-nozzle cap high temperature and pressure seals. The seals w1ll be evaluated as alternates to the presently used solid metal 0-ring.

The design criteria and scope drawings defining the revisions to improve the KRR safety clrcuit have been prepared and transmitted for comment. This revision will exclude the 1706-KRR control instrumentation as part of the safety circuit, but will expand the safety circult to a complete three channel system.

CGI-844 - 100-K Coolant Backup System

Detail desion is 10 percent complete. Specifications for the steam turbine and gear units for the 190-K Main Pump House, the pump and gear units for the new diesel pump house, and the modifications to the Navg surplus diesel engines have been approved.

Design of the diesel pump station portion of this project has been assigned to the Spokane, Washington office of H. E. Bovay, Jr. Englneers by the local Bovay office. This split in work location has required several visits to Spokane to check design progress and discuss questions of scope significance.

CGI-883 - Increased Process Water Flow - 100-K

Detail design is 33 percent complete. The design criteria have been approved by the Project Representatives.

Requests for purchase of engineered material bave been transmitted for the 13.8-4.16 KV load tap changing transformers and $4.16 \mathrm{KV}$ voltage regulators, Building $151-K$ grounding reslstors, and motor control centers for the $181-\mathrm{K}$ River Pump House.

A requisition has also been prepared for the purchase of new low lift pumps. Originally it was intended that the low and high lift pumps would be purchased as a set; however, on-site testing indicated a satisfactory low lift pump, but that an acceptable high lift impeller has not been developed. A study has been completed regarding the feasibility of installing the new low lift pumps in the 190-K Main Pump House prior to the completion of the electrical modifications. Preliminary results indicate it is technically feasible to make these changes; however, precautions will be required to insure that the emergency electrical system is not overloaded.

CGI-884 - Rear Face Crossunder Lines B, D, DR, F, and H Reactors

Scope design is 90 percent complete; detall design 80 percent. Scope drawings for the crossunder line installation at the 105-F Reactor have been transmitted for comment. 
Remote Rear Face

The actuator and TV equipment now installed under the rear elevator in $\mathrm{KE}$ reactor continued to function satisfactorily. No evidence bas been observed of degradation of the TV signal. New seal designs have been tested in the laboratory for both the ball valve and the flapper valve. Test quantities of both types of valves with new seals are being prepared for the next outage. In an effort to reduce valve cost, a new Plap valve design, designated Mark VI, has been made and castings have been ordered offsite for prototype fabrication. A partial assembly of a balanced hydraulic charging mgchine intended for use with the remote rear face equipment for charging during operation has been assembled and given a preliminary functional test.

Overboring

Several tests of a machine designed to bore out the cast iron thermal shield and in-board do-nut have been made which demonstrate weakness in the mechanical feed part of the equipment. The existing machine was designed to permit a $200 \mathrm{mll}$ overbore at C reactor. Modifications are being designed for it to permit its use in a preliminary 550 mil overbore test. Meanwhile, we have negotlated a contract w1th Norfin, Incorporated, of Seattle, to bufld two new dual borlng machines as second generation prototypes to be used in a planned 550 mil overboring test at $C$.

\section{Expansion Hardware}

A number of front and rear nozzle assemblies designed for 200 mil overbore have been recelved and subjected to preliminary laboratory testing. One front assembly which incorporates a check valve was tested to obtain an Indication of potential charging damage to be expected in charging fuel elements through the check; no damage was found in preliminary tests. The front assembly was also tested for pressure drop and found to exhibit less than balf the pressure drop characterlstic of the present hardware. Fleld Auxillarles developed for us a programmed welding device which has proved to be very efflcient in welding a small gunbarrel flange to the centering flange to effect a fixed gas seal.

\section{Instrumentation}

Initial instiallation of an effluent temperature distribution display was made at $K E$ reactor.

All equipment for off-reactor test boring to demonstrate boring of shield holes for the octant monitor system has been assembled. Initial testing which should have been complete was delayed by the pipefitter strike.

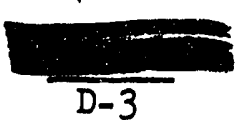


The bumper slug charging mochine was used in an attempt to charge bumper slugs into D reactor: " It falled because greater than expected tube curvature was found. The machlne stalled out after charging 18 slugs and, on the last tube attempted, was broken in an abrupt stall with 130 Ib. alr pressure. It has been returned to the shop for repalr.

NEW PRODUCTION REACTOR WORK

\section{NPR Fittings}

Development work was completed and recommendations made to Process Design on the rear tube to nozzle joints. The recommended joint is a threegrooved rolled folnt on the basis of all testing to date. Two nozzle closures have also been found sat1sfactory and appropriate recommendat1ons have been made. An entirely sat1sfactory front tube to nozzle jolnt has not yet been established.

\section{Instrumentation}

Principal Instrumentation activities continued to be design review rather than development, as development personnel assisted in the preparation of nuclear instrumentation speciflcations and in the review of flow monitor proposals, in addition to more routine review of other drawings and specifications.

\section{Design Tests}

Design Tests 1063 - Dynam1c V1sual Monitor; 1074 - Ball Level Detector; and 1078 - Grout Seal Assembly are completed with the issuance of final reports. Initial tests were performed on an expanded version of Design Test 1067 - NPR Duwp System Evaluation - which is beling run concurrently, as far as that is possible, w1th the new series of Process Tube Rupture Tests. Design Test 1081 - Sealing Plug for Inlet Barrler Wall Penetration - was received. 
PLANT ENGINEERING OPERATION -..

DRAFTING OPERATION

DECLSSSFIED

Summary of services provided by the Drafting Operation is as follows:

New Englneering Drawings

Revislons, Layouts and Sketches

163

Milcrofilm prints reproduced

Microfilm drawings added or retired 4509

Ozalid check prints reproduced

Customers serviced - Microfilm files 218

Customers serviced - Catalog files 39

Catalogs added to files

The new Thermofax reader-printer was installed this month. Except for a few minor adjustments required, the unt has performed very well. The reproductions of the micro: $1 \mathrm{~lm}$ drawings are larger than those produced by the previous untt and they are clearer. Four additional Thermofax readerprinters for installation in 100-B, K, D, and H Areas have been received.

\section{WATER PLANT AND UTILITIES ENGINEHRING}

$4500 \mathrm{HP}$ Motors

Preparation of the overall program for rewinding 36 of the 4500 HP motors is underway. In pursuance of this program, the first motor is currently in the General Electric Shops. (SPOtt lendsi Oregon) belng rewound."

At the request of the Maintenance Manager, assistance was given to 100-D Malntenance Operation in the testing and repair of \#2 DR 4500 HP Motor after fallure of a coll in A phase. During the A.C. overpotential test made after isolation of the faulted coll, a coll in B phase falled at $13 \mathrm{KV}$. It was then recommended that the f1rst coll in C phase also be 1solated to minimize phase transients. This was done and the unit was successfully returned to service.

Absistance was given to 100-F Malntenance Operation in the testing and repair of 4500 HP motor \#2 190-F after fallure of a stator coll. The faulted coll was isolated and the motor successfully returned to service.

Transformer Capacity $B, D_{2}$ F Filter Plants

Several proposals were made and studled to provide increased transformer capacity at the 183. Filter Bullding at 100-B, D, and F Areas. Electrical load at these bulldings exceeds the rating of one transformer ( $300 \mathrm{KVA}$ ) when and if the second transformer is out of service. Proposals include methods of economically obtaining 5000 KVA capacity. A study is underway to determine $1 f^{\prime}$ extsting $3000 \mathrm{KVA}$ transformers can be uprated sufficiently. 


\section{Effluent Decontamination}

\section{DELUSSFFED}

BW-66970

The first test run of the pllot plant for effluent decontamination with aluminum turnings was terminated after about 800 hours. A review of test data of the inftial run furnished by the Hanford Laboratories Operation conducting the tests Indicates good conflrmation of the parameters and assumption used for budget studies for a full-scale unit. Data from the second run, at higher flow rates, is not yet available.

\section{Columbla River Studies}

River flows followed forecast rates except for a few days when flows were reduced to completely sur-charge the reservoir at Coulee. Re-evaluation of storage by the Federal agencies indicating that there was plenty of water avallable, has resulted in Bonneville Power Authority increasing flows. This results in improved cooling conditions at Hanford. Continuing cold weather in Canada has reduced melting and the river flow is expected to continue a normal slow fall.

\section{Test Supporting Coal Contracts}

Acceleration tests were made at the 184-D Power House to determine the comparative performance of Independent Coal Company and Northern Pacific Rallroad Company coal. It was determined that these coals can be adequately handled by our equipment, but that a considerable variation in technique would be required for 1deal performance. These and prevlous tests also indicate the need for further study of the instrumentation in order to best assure required steam bicking.

\section{Emergency Personnel Shelters}

At the request of Hanford Operations Off1ce, Atomic Hergy Comission, a review of emergency personnel shelter requirements was made and order-ofmagnitude cost determined. The basic premise for this review ras that adequate emergency cooling would be maintained at all reactors unless plant facilities were destroyed. Time did not permit a thorough engineering evaluation and optimization of all factors, but sufficlent information was developed to point out frultful flelds for study in evaluating adequacy of plant facilities for emergency operation.

\section{Rear Crossheader Expansion Jolnts I Reactor Bullding}

As reported earlier, the principal rear face hardinoce problems which threaten continuity of operation result from vibration and thermal stress. Installation of a crossheader expansion foint is under study as a means of reducing rear header vibration and thermal stress. Production Test Authorization PT-IP-356-AE, "Rear Crossheader Expansion Joints, 105-H Reactor, HW-66650, has been prepared to authorize a test of an expansion joint on one header at 105-H.

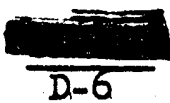


HW- 66970

PROJECT ENGINEERIING OPERATION

\section{DECLASSFIED}

PROJECTS

CG-706 - Installation of Improved Reactor Ges Instrumentation - 100-B, C, $D_{2} D R, F$, and $\mathrm{B}$

Beneficial use of the equipment was obtalned at 105-D on September 18, 1960. Beneficial use has not yet been obtalned at 105-DR and H.

CGI-791 - Reactor Confinement

An accelerated target schedule for beneficlal use, as proposed by the AEC, has been set up. This provides for beneflclal use of 100-F Area by October 21, 1960, and of all areas by Jamary 20, 1961. The J. A. Jones Construction Company has been requested to provide an estimate of additional costs which will be incurred to meet the accelerated schedule.

Phase I - Fog Spray

An order was placed for the new dual differential countrate meters on September 23, 1960. This order was not placed as previously reported because of drift problems reportedly encountered on similar meters in use elsewhere on the plant. These were investigated prior to placing the order.

Phase II-B - Filter and Sample Bulldings

Acceptance teating has been in progress along. With the completion of construction work at 100-F Area since September 19, 1960. This "plecemeal" approach was agreed to in an attempt to finlsh the work in this area as soon as possible. Problems involving the sealing of the rentilation fan housing and gasket seals around the cell cover blocks have not yet been solved. Work is approximately two percent behind schedule on this phase of work.

Phase III - Ventilation Modifications and Tie-ins

The work stoppage by the CPFF pipe fitters lasted From September 19 to October 2. Work by other crafts, particularly electrical, continued satisfactorily.

CGI-802 - Process Safety Monitoring System - High Speed Scanning Type For Temperature Monitoring

Formal acceptance testing on this proiotype equipment was started September 19, 1960, at Mon1tor Systems, Inc., Fort Washington, Penna.

CGI-861 - Expansion of Electrical Distribution Systems - Buildings 105-B, D, and F.

The purpose of this project is to design, procure and install equipment to modify and adequately expand the 105-B, D, and F electrical distribution systems. A Work Release was issued to J.A. Jones, and construction of the concrete outdoor transformer pads was started at 105-B during the week ending september 30. Transformers for the new substations have been received. 


\section{DECLASSFIED}

$\mathrm{HW}-66970$

CGI-883 - Increased Process Water Flow - 100-K Area

The second rewound primary pump motor was recelved on plant September 26, and installed on primary pump No. 2 located at 190-KW on September 29.

MJA's 21, 25, and 29 - Pressure Monitor Repairs and Modif1cations - 105-C, $\mathrm{KE}, \mathrm{KW}$, and $\mathrm{H}$

During this month the Ge buyer visited Panellit, Inc., to review the purchasing aspects of this work. A bid package was subsequently recelved on September 28 and is being evaluated.

MJA-8 - Ball 3X Electrical Modiflcations - 105-B, D, DR, F, and H

The purpose of this MJA is to modify and upgrade the Ball $3 X$ electrical systems at 105-B, D, DR, F, and B Reactors. Prior to this report, work had been completed at 105-B, F, and H Reactors. Work was completed at 105-D during an outage September 12 through 16, 1960.

PROJECT PROPOSAIS

Project Proposals Returned Unaproved

CGI-887C Critteal Mass Monitoring All Hanford 105 Bulldings (Returned to Ceneral Electric Company on September 20, 1960, for re-evaluation of scope.)

CAI-892 Ventilation Improvements - 181 Bufldinge (Returned to General Electric Company September 13, 1960, without action. Recalled because of higher priority projects of greater mutual benefit.)

Project Proposals Approved

None.

Project Proposals Submitted to AEC

CGI-865 Continuous Air Monitoring All Reactors (Directive in preparaRev. 1 tion for extension of physical completion date to November 30 , 1960.)

CGI-910 Process Tube Hot Cell, 105-C

Other Projects Awaiting AEC Approval

CGI-824 Remotely Operated Tube Closure Dev1ce, KE Reactor (Formerly

Rev. 2 "Remotely Operated Cap Remover, KE Reactor.")

CGI-844 100-K Area Coolant Backup (For remaining requested funds,

Rev. $1 \$ 1,865,000)$

CAI-868 Columbia R1ver Scale Model

Rev. 1

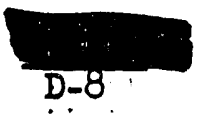


CGI-883 Increased Process Water Flow, 100-K Area (For remaining requested
Rev.2 funds, $\$ 4,773,000$ )

CGI-889 Effluent System Modiflcations - 100-B/C (For remaining requested funds, $\$ 451,000$ )

CGI-900 Modiflcation For Use of Self-Supported Fuel Elements - C Reactor.

Requests Recelved for Project Preparation

CAI-868 Columbia River Scale Model

Rev. 2

CGI-865 Continuous Alr Monitoring - All Reactors

Rev. 1

R-29089 Analog to Digital Converter System for Temperature Monitoring $B, C, D, D R, F$, and $H$ Reactors.

R-29133 Instrumentation for Graphite Stringer Thermocouples - Existing Hanford Production Reactors.

CPFF COISTIRUCTION SERVICE CONILACTOR - LIAISON

We have 1ssued five new work orders and supplemented five project releases for a total of $\$ 528,600$ to J. A. Jones in the month of September.

The J. A. Jones f1tters walked off the job at noon September 19, 1960, over a jurisdictional dispute with the sheetmetal craft on hood work in
200 Areas.

\section{PLANT FORCES WORK REVIEW}

The Labor Standards Board approved two jobs. for assignment to Plant Forces, which are estimated to cost $\$ 88,637$.

RT Jessen:dgen

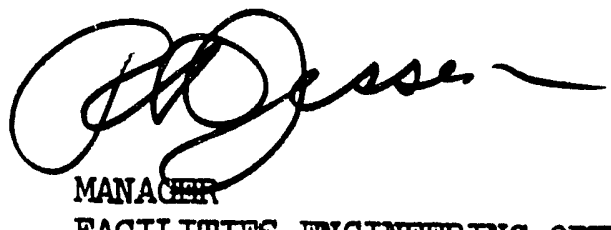

FACILITIES ENGINGEERING OPERATION 


\section{NPR PROJECT OPHRATION}

\section{PROCESS DESIGN}

Research and Development

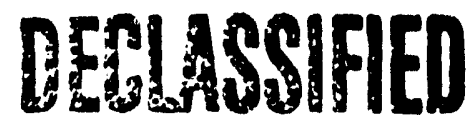

Physics calculations for a superheat feasibility study for an NPR type reactor have shown that enrlchment does not vary signiflcantly for lattice sizes smaller than ten inches. Calculations thus far indicate a possible configuration of a ten Inch lattice w1th a 12 rod $\mathrm{VO}_{2}$ cluster enriched to about $3-1 / 2$ percent in a stainless steel process tube approximately $2-1 / 2$ inches in diameter. The individual fuel rod will be about $1 / 3$ inch in diameter.

Analytical and design activities on an evaluation of a Russian Superheat Reacior are under way. Deslgn data and operating parameters have been developed based on an extrapolation of the limited information avallable. Systems based on this design data are to be generally envisioned so that capital and operating costs for the plant may be developed.

NPR conversion studies are concentrated on an up-dating of the Federal Power Commission report. Preliminary studies of the NPR lattice witb oxide fuel elements reveal no physics limitations which would prevent fuel exposures considerably higher than 10,000 MND/T.

Project CAI-816

Simulation of primary loop emergency dump englneering is now under study. Purpose of the test is to determine final maximm temperatures permissible so that minimum durup tank dimensions can be determined. Tests to date indicate no evidence of excessive vibration up to tank water temperatures of $180^{\circ}$. There 18 no evidence of steam escaping from the surface of the water even at the higher tank temperatures indicating that the tank size can be held to a minimm.

At the request of the Atomic Energy Commiss10n, both General Electric and Kaiser Engineers have made estimates of cost and schedule to set up and run tests of a primary coolant pump and drive in the fleld. The studies were made to provide information needed by the AEC in considering the advisability of testing the pumps and their drives in the field and the extent of the pump testing in the factory. Based on the current construction schedule, it was estimated that a full power test at rated primary conditions could be started in the e1rst quarter of 1962 . General Electric estimated a cost of $\$ 320,000$ to install equipment and run a one month fleld test. For a similar test, Kalser Engineers estimated an expenditure of $\$ 473,000$.

The proposal to ins tall the decontamination equipment in 109 Bullding has recelved General Electric scope approval. Appreciable capital cost savings are possible due to reduced piping runs and the elimination of the decontamination bullding.

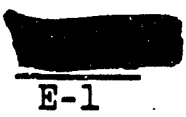


Project CAI-816 (Continued)

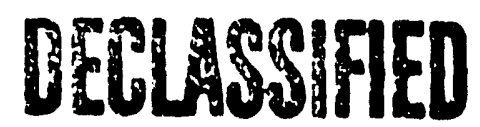

The Phase II superstructure bid package for the 105 and 109 Bullding was released to Kalser Englpeers on schedule. Th1s large b1d package contalned over 1000 separate design Items prepared by Burns and Roe and General Electric.

The most recent developments and the latest mechanfcal, hydraulic, control and electrical drawlags prepared by ANF Atomlcs durlag the system analysis and scope design of the Fuel Element Handing System were revlewed and discussed. Some additional work and clariflcation will be required on the control drawings to make them compatible w1th the mechanlcal drawings and Hanford requirements. A final review of these 1tems and the over-all package contents is contemplated before the AMF Atomics issues the final report on Phase I (System Analys 1s and Scope Desiga).

A vendor pre-proposal conference on flow monltoring wes beld August 2, 1960. Technfcal proposals were recelved on September 6, 1960. Thirteen proposals were recelved and evaluated as to vendor qualiflcatlons, englneering ab1lity, manufacturing ablilty and technical design. A technical teem of NPR assigned personnel has started a serles of vendor conferences at BAPO and at the vendor plants to obtain additional technical information to allow selection of vendors to produce prototypes for eveluation. Placement of the production order w1ll be based on prototype evaluation.

\section{DEVELOPMENT AND TESTING}

Listed below are signiflcant developments for the New Production Reactor primarily reported by the Equipment Development Operation of Facilities Engineering.

A backlog of desirable tests has accumulated which need to be performed in the Component Test Loop necessitating the establishment of priorities. Early in September, the Component Test Loop was used to cycle fittings designed to test closures, Grayloc connector couplings, rolled zlrconlum tube joints, and Grayloc-type zirconium tube-to-nozzle jolnts. Late in the month, the Component Test Loop wes used to perform primary loop dumping tests needed to size the proposed energy dissipator. Components were assembled to permit the resumption of process tube rupture testing early in october.

Results of cycling test flttings on the Component Test Loop include: (1) a spiral wound gasketed assembly (asbestos and stainless steel or Inconel) utilizing a small tongue-and-groove seal seat conflguration has been recomended for nozzle closures; and (2) same leakage has been observed at Grayloc-type zirconlum tube-to-nozzle closures which requires extension of testing; one assembly fabricated by Gray Tool Company and employlng a standard Grayloc seal ring did not leak, whereas a second assembly made at Hanford leaked and a third assembly fabricated by Gray Tool Company but employing a non-standard seal ring with a larger inside diameter (to minimize projections that could interfere with fuel element charging) also leaked.

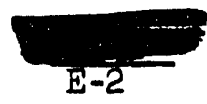


Time response tests were performed on three Englehard clamp-on resistance temperature detectors in the Component Test Loop. In one series of tests the time lag was approximately ten seconds, of which the pipe wall contributed in the arder of elght seconds. These data are consldered order-of-magnitude and highly dependent on the internel flow velocity.

Nuclear Metals reported the successful fabrication of a three-inch pipe section of a coextruded zirconium to carbon steel joint. This test specimen will be shipped to Hanford for evaluation.

Progress on procurement activities that invoke prototype requirements include:

Technical discussions were held on September 12, 13, 14 and 15, 1960, w1th Chandler-Evans, Atwood and Morr1ll, Mason-Ne1lan, and Crane Company, the four companies selected to participate in the prototype program for process tube inlet valves and process tube diversion valves. The engineering content of these discussions was forwarded to Kalser Englneers for Inclusion in the documented award to each $11 \mathrm{rm}$.

Thirteen engineering proposals were recelved on process tube flow monitoring. Only two vendors proposed electromechanlcel concepts to meet the high rellablilty requirements of the specification; all others proposed electronlc systems. To date, no vendor has proposed a system that is dompletely sat1sfactory, though several proposals stand out from the rest. To date, the prototypic approech to flow monitoringiaping is to be justifled and hes accentuated the critical engtneerlingudo of blend of required functions, desired rellabllity (c1rcult and component selection), and mintmum cost. A letter to the Atomic Energy Commission recommending vendors to be included in the prototype flow monitor progrem is being drafted.

Recomendations were forwarded to Kalser Englneers on September 16, 1960, for participants in the prototype program for process tube expansion bellows. It was recomended that five or six participants be included in the prototype program since (1) individual prototype costs would be small, (2) competition could reduce the price of the production order significantly, and (3) variations in proposals made it desirable to evaluate single and two-ply convoluted bellows and welded dlaphragm bellows.

\section{DECLSSFFED}

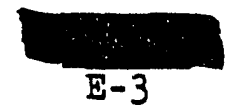




\section{- $\quad$ on}

FIEID AND OPERATIONS ENGINHEERING

Construction

$105-N$ Building

\section{DECLASSFIED}

All the elevator casings have now been completed except the one for the $S$ elevator. Thls one has been driven to approximately elevation $(-) 80$ feet. When completed, thls casing will be driven to approximately elevation (-) 95 feet.

Total concrete yardage placed in this bullding as of September 27, was about 8,400 cubic yards. The average placement rate during the period from August 24 through September 27 was approximately 126 cubic yards per working day.

The structural steel for the support of floor slabs has been installed in areas $1-A$ and $5-A$.

Drainage piping and the penetrations for service and process piping below elevation (-) 16 feet are now about 90 percent complete. The embedded portion of the elevator hydraulic lines has now been completed.

The electrical grounding mat below the bullding is now essentially complete except for a few small areas whlch are awalting final excavation and fine grading.

\section{9-N Building}

Approximately 1,580 cublc yards of concrete were placed in this building in the period Auguat 24 through September 27. Total yardage to date as of September 27 is about 4,410. Average placement rate during this reporting period for 105 and 109-N combined is therefore approximately 195 cub1c yards per working day.

\section{1-N Builaing}

Concrete has now been placed for the floor slab col:mns and roof slabs. The basement floor slab and basement walls have a: so ..een comp.eted.

\section{3-N Bullding}

The basement floor slab and walls are in place and forming is in progress on the ground level floor slab.

163-N and 183-N Butlaings

Excavation, forming, and placing of concrete continued throughout this reporting period. The clearwell concrete is nearly complete. 
166-N Fuel 011 Starage

Excavation work has been started.

18I-N Builaing

Concrete has now been placed in about 50 percent of the operating floor slab. The subcontractor is currently installing penetrations for electrical, piping, etc., in the remaining 50 percent of this floor slab.

\section{4-N Standby Power House}

The outside wall footings and the boller footings are in place. Work progressed during this period on the turbine generator supports, and footlings have been poured for two of the fuel oil day tanks.

1734-N Building

The concrete block walls have been erected.

$230 \mathrm{KV}$ Transmission Iine - Project CAE-853

The subcontractor, Cleveland Electric, started work on this facility on September 19, 1960.

\section{Graphite}

Production machlaling of moderator detalls continues at a very low rate. Resolution of the notching operation is still belng investigated by Kaiser Engineers w1th primary emphasis on modifications to the Arrowsmlth machine. Contacts have also been maie by Kaiser Inglneers with other machine tool manufacturers in an effort to develop supplemental machining facilities for the notched detalis. Actual completion of finlshed detalls now stands at about 15.5 percent compared to the scheduled 34 percent.

The first carload of core material from National Carbon Company was unloaded at the 2101 Building on September 21. The balance of this order is scheduled at an approximate.average rate of one to two carloads per week unt1l completion.

Due to unacceptable purity tests from several beats of Great Lakes reflector material, the vendor has decided to gas purify all questionable heats. Of the approximately 2,800 bars remaining on this order, about half require this additional processing. The remaining halt is now enroute.

\section{$\underline{\text { Zirconium }}$}

The first trial run on one of the autoclaves was made on short pieces of zirconium process tube and coupon samples. The 38-hour run showed a.ll material to exhibit a satisfactory oxide film with no staining attributed to the autoclave system. The test did disclose the need for more unf form heating between the top and bottom locations. Work toward this end is progressing. Final checkout of the acid etch station is being performed.

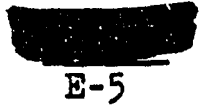


Progress at the tube fabricators is as follows:

Iittle progress has been made at Chase Brass during this perlod. Th1s vendor has been working toward Improved welding techniques.

All tubes on the Allegheny-Ludlum order are now at Tube Reducing Corporation walting reducing and finlshing operation. Approximately half are In the Iinishing operation.

Harvey Aluminum shlpped approximately 50 tubes on the pllot order September 30, 1960. The remainder of the tubes are now being inspected with sh1pment scheduled for October 31, 1960, along with the first lot of 30 production tubes, which have been cold-drawn and are being conditioned preparatory to inspection. Progress on the production order is ahead of schedule.

\section{Primary Loop}

To help reduce to a minimum the total time required to process shop and erection drawings and procedures and reports, submitted for approval by the primary plping subcontractor, the following procedure has been initiated:

All approval data, except 1tems of a contractual nature, will now be submitted by the contractor directly to General Electric. General Electric will process these 1tems in cooperation with Burns and Roe, Inc. and will return processed material directly to the primary piping subcontractor with appropriate copy coverage to Kaiser Engineers. This procedure eliminates the time delay of the intermediate steps of receipt and return of approval data through Kalser Englneers, but in no way changes the responsibilities, contractual or administrative, of the parties involved.

Burns and Roe assigned a metallurgist to Rlchland for fifteen days to work jolntly with General Electric personnel to expedite the processing of approval data submitted by the primary piping subcontractor. During the per1od, 93 1tems were processed and returned to the subcontractor. In addition, the Burns and Roe representative jointly participated with General Electric personnel in several meetings to orlentate interested parties, including lower tier contractors for the primary piping system, in the requirements of the specification.

A resident Llalson Engineer has been located in Richland by Burns and Roe. His duties will be to work with the Genergl Electric Primary Loop Engineer in maintaining close survelllance over the primary loop constructor's act1vities affocting the Architect-Engineers' interests and project responsibil1ties. This move will serve to expedite the completion of the engineering effort and approvals required by contract and will insure that adecuate provisions are made for conformance with applicable codes, standards, and contract requirements.

\section{Procurement}

Following is the status of procurement as of September 28, 1960:

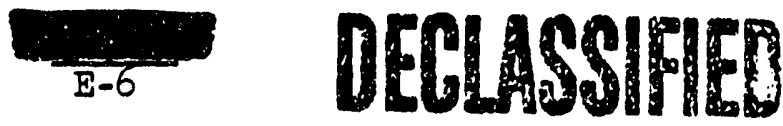


Reactor Plant

BW-66970

General Electric Originated - Kaiser Engineers Purchase

59 Open Requisitions - Estimated Cost

57 Open Purchase Orders - Actual Cost

$\$ 6,817,621$

$1,891,088$

3 Subcontracts - Actual Cost (2 camblned with B\&R) 10,682,223

16 Complete Purchase Orders - Actual Cost

$\$ 19,480,855$

General Electrlc Originated - GE or ABC Purchase

3 Open Requisitions - Estimated Cost

8 Open Purchase Orders - Actual Cost

$\$ 204,500$

$12,870,181$

$\$ 13,074,681$

Heat Dissipation Plant

Burns \& Roe Orlg1nated - Kalser Rnglneers Purchase

53 Open Requisitions - Estimated Cost

$\$ 6,375,300$

37 Open Purchase Orders - Actual Cost

$11,335,921$

14 Subcontracts - Actual Cost Holding 6 Requisitions (Iock sets)

2 Complete Purchase Orders - Actual Cost

$13,675,107$

55,694

$\$ 31,442,022$

NPR Related

General Flectric Originated - Kalser Engineers Purchase

5 Open Requisitions - Estimated Cost

6 Open Purchase Orders - Actual Cost

$\$ \quad 25,300$

4 Purchase Orders Complete - Activel Cost

40,568

56,391

$\$ \quad 122,259$

Total - All Orders

$\$ 64,119,817$

Administration

The following materlal was 1ssued by Drawing and Specification Control durIng the month:

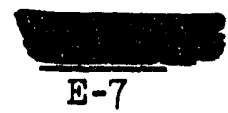


Routine Work Processed from August 22 through September 18, 1960

Draw1ings

Specifications

Criteria

Requisitions

AIT's

Other

Total
873

52

28

74

68

Revlews were completed and formal coments were offered on engineering materials as follows:

On Detall Drawings $\quad 150$

On Specilications 20

On Scope 11

On Criteria 0

On ATP's

Total

187

\section{Operational Planning}

Work was Inltiated on developing standard source cards on which to log equipment data. These cards are the inftial step in equipment description preparation.

A document covering safety system operation is in preparation. This will be utilized to check design and serve as a basis for maintenance procedures.

$$
\text { (r) intini }
$$

A review of the assignments of responslbility, authorities, and working agreements between NPR Project and Manufacturing Section related to operational start-up activities was initiated. Arrangements will help to assure proper distribution of charges by both components for these activities and for transfer of personnel or of their services between components to obtain the best use of operating experfence and of acquired N-Plant background.

\section{CONSULTING ENG INEHERS}

The data supplied by the General Electric Company for the original FPC Report was reviewed and the results of the review recorded in $\mathrm{HW}-67003$ to be transmitted to the AEC.

The evaluation of the Beloyarsk Russian superheat reactor is proceeding on schedule. Design criterla have been prepared for a single reactor unit with a rating of $318 \mathrm{eMW}$. The physics of the reactor are being studied for fuel exposure levels of 2300,5000 and $10,000 \mathrm{MWD} / \mathrm{T}$. Discussions are to be held with the Architect-Engineer employed by the Atomic Energy Commission to study the power generating facilities of the several conceptual reactor plants in Milwaukee, October 12-14, 1960.

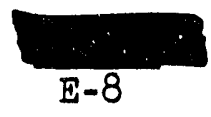


HW -66970

\section{PROGRAM EVALUATION}

Design Status

Wt'd. Certified Actual

Reactor Plant as of $10 / 1 / 60$

Total Schedule of Complete

Title I

Scope

100

99.7

Title II

Drawings (No. Incr. from.2100 to 2200)

$\begin{array}{r}70 \\ 8 \\ 8 \\ 4 \\ 10 \\ \hline\end{array}$

74.0

92.0

32.0

Requisitions

ATP's

Development and Testing

Total

100

17.0

78.2

75.7

25.9

9.1

$75.0 \quad 71.0$

$\begin{array}{ll}70.0 & 70.3\end{array}$

Heat Dissipation Plant as of 10/1/60

Title I

Scope Criteria

100

98.5

Title II

Detail Design

65.0

79.0

Req'd $\frac{\text { No. Issued to } 9 / 17 / 60}{\text { Schedulad }}$

Criteria

Preliminary Drawings (bid)

Detail Drawings (for const.)

23

717

726

Specifications (bid)

165

Requisitions

ATP's

176

$\begin{array}{rr}23 & 21 \\ 564 & 575 \\ 329 & 390 \\ 99 & 110 \\ 106 & 117 \\ 0 & 0\end{array}$

Composite Design Completion as of 10/1/60 (Reactor and Heat Dissipation Combined)

Certifled Actual

Total

Schedule ¿ Complete

72.0

$77 \cdot 5$

Cost Estimate

The last project cost estimate was 1ssued on June 30,1960 . See the July record report for summary.

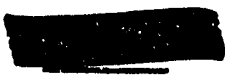




\section{Schedules}

On September 6, 1960, the AEC directed Kaiser Engineers to proceed w1th placement of 105 Bullding superstructure concrete using Kalser Englneers.. forces. The letter further instructed that electrical work, embedded pipe and reinforcement steel placement is to be by flxed price subcontractors, "to the greatest extent pract1cable." The ent1re 109 Bullaing superstructure, except final setting of process equipment, pipe insulation and finish painting, will be by fixed price contract.

During the month of August, AEC 1ssueci Revision 1 of the Certified Construction Progress Schedule.

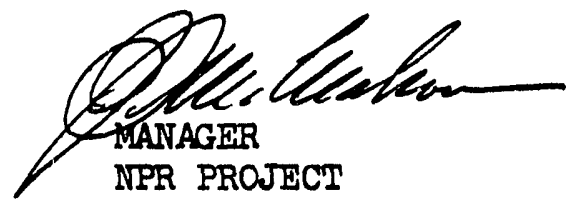

JS Mcilahon:mf

\section{DECLASSFFIED}


FINANCIAL SECTION

\section{GENERAI ACCOUNTING SECTION}

During September, five IPD employees attended professional soclety meetings and IPD recelved a refund for a trip taken in August. The net cost (total less the refund of $\$ 143.61$ ) was $\$ 514.17$.

Provision was made for the quarterly Equijment expenditure pattern and PA\&C midyear rev1ew September 21, 1960.

The annuri physlcal inventory of Reactor and Other Special Materials was taken as scheduled on September 29, 1960.

\section{PRODUCTION COST \& BUDGET SECTION}

Work In Process Inventory at June 30, 1960, was priced at current rates for comparison with book values. Minor discrepancies in the method of preparing the AEC Product report were discovered and changes recomended.

The "Distribution of Power Cost" document issued monthly was revised to present the same information in a condensed form (2 pages vs 10 pages) without a sacrifice in quality.

Essential Material and Frozen Lunch inventories were observed in H Processing on August 25, 1960.

\section{PERSONNEL ACCOUNTING}

Total number of personnel assigned to the Department at month end is 2,260 a decrease of 15 from the previous month.

During the month, suggestion awards aggregating $\$ 934$ were paid to Department employees. Jalendar year to date awards aggregate $\$ 5185$. Authorized allocation for 1960 is \$11 875 .

\section{AUDITING}

The absence and injury records pertinent to the 79-day period ended at midnight September 19, 1960 were examined. Nothing was found to prevent the Department from achleving the fourth consecutive HAPO General Manager's Safety Award.

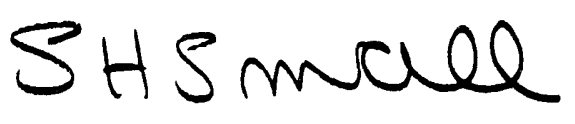

SH Small:vfr

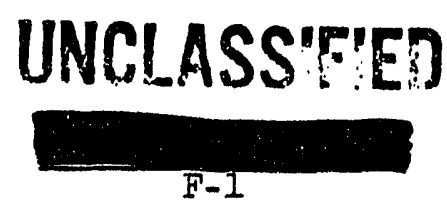




\section{UNCLASSIFIED}

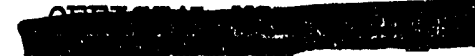

\section{RERATIONS PRACTICES OPERATION}

Three technically trained candidates were interviewed with no offers extended. Two previous offers were rejected and three offers remain open at month end Including one to a $\mathrm{PhD}$. Three employees transferred into the Department from other HAPO components and one from GE-Schenectady. One monthly employee transferred to Contract and Accounting Operation. Four exempt employees went on leaves of absence-- two retumed to school and two entered military service.

A total of $\$ 145$ was pald to 15 suggesters for 16 suggestions. The largest award was $\$ 30$.

Communtcations included publication of nine Management News Bulletins, one Round Table Gulde, four Headilners, and seven priority messages. GE NEWS coverage included seventeen 1tems about IPD activities totaling 244 colum Inches.

Six securlty violations occurred during September. One hundred and elght medical treatment injury cases were treated during the month. The Department completed 6,835,000 man-hours in 564 deys without a disabling injury. At midnight 9-19-60, IPD attained 1ts 4th consecut1ve General Manager's Safety Award. Selections have been completed and orders placed with Stores.

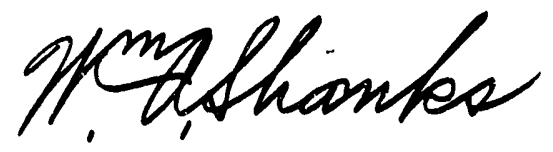


SIGNIFICANT REPORTS ISSUED

\begin{tabular}{|c|c|c|c|c|}
\hline Number & Class'n. & Author & Date & Title \\
\hline $\mathrm{HW}-66787$ & Conf.-Undoc. & L. M. Keene & $9-20-60$ & $\begin{array}{l}\text { Scope of Work - Contract } \\
\text { DDR-111 Downcomer Or1f1ce } \\
\text { Plate and Crossheader } \\
\text { Expansion Joint Tests-100-K } \\
\text { Area. }\end{array}$ \\
\hline $\mathrm{HW}-66746$ & Unclass. & E. L. Ether1dge & $9-12-60$ & $\begin{array}{l}\text { Development Test - Field } \\
\text { Test Equipment for Testing } \\
\text { the Integrity of Filter. }\end{array}$ \\
\hline $\begin{array}{l}\text { HW-SA- } \\
1988\end{array}$ & Unclass. & H. W. Heacock & $9-15-60$ & $\begin{array}{l}\text { The Existing Reactor Con- } \\
\text { finement Program at Han- } \\
\text { ford. }\end{array}$ \\
\hline iN-66774 & Secret & P. H. Button & $9-22-60$ & $\begin{array}{l}\text { Reactor, Plant Engineering } \\
\text { Short Range Program In } \\
\text { Support of Reactor Oper- } \\
\text { ating Continuity. }\end{array}$ \\
\hline- & Unclass. & J. H. Fastabend & $9-12-60$ & $\begin{array}{l}\text { Status Report - NPR F1tting } \\
\text { Development Activity. }\end{array}$ \\
\hline- & Unclass. & J. E. Fastabend & $9-21-60$ & Trip Report - NPR Tooling. \\
\hline $\mathrm{HW}-66735$ & Unclass. & $\begin{array}{l}\text { R. G. Colwell } \\
\text { J. R. Spink }\end{array}$ & $9-8-60$ & $\begin{array}{l}\text { DP-1074 - Ball Level } \\
\text { Detector Test Report. }\end{array}$ \\
\hline HW- 66739 & Unclass. & $\begin{array}{l}\text { R. G. Colwell } \\
\text { J. R. Splnk }\end{array}$ & $9-8-60$ & $\begin{array}{l}\text { DT-1078 - Grout Seal } \\
\text { Assembly Test Report. }\end{array}$ \\
\hline $\mathrm{HW}-66783$ & Unclass. & E. Hollister & $9-14-60$ & $\begin{array}{l}\text { Progress Report, Octant } \\
\text { Monitor Drililng Test. }\end{array}$ \\
\hline HW-66804 & Unclass. & H. F. Jensen & $9-16-60$ & $\begin{array}{l}\text { Report on Chemical Descal- } \\
\text { Ing of } 105 \text { Reactor High } \\
\text { Tank PIping. }\end{array}$ \\
\hline$H W-66815$ & Unclass. & E. Hollister & $9-19-60$ & $\begin{array}{l}\text { Polson Spline Use Study } \\
\text { and Recommendations. }\end{array}$ \\
\hline $\mathrm{HW}-66540$ & Unclass. & A. J. Lindsay & $8-17-60$ & $\begin{array}{l}\text { Comments on HWS- } 6511 \text {, } \\
\text { Control Rod Position Indica- } \\
\text { tion System. }\end{array}$ \\
\hline $\mathrm{HW}-66619$ & Unclass. & A. J. Lindsay & $8-13-60$ & $\begin{array}{l}\text { Finai Report - DT-1063, } \\
\text { Evaluation of Dynemic } \\
\text { Visual Monitor. }\end{array}$ \\
\hline EWS-7973 & Unclass. & A. N. Iverson & $9-14-60$ & $\begin{array}{l}\text { Speciflcation for In-Core } \\
\text { Gamma Flux Detector Assembly. }\end{array}$ \\
\hline
\end{tabular}




\begin{tabular}{|c|c|c|c|c|}
\hline Number & Class'n. & Author & Date & T1tle \\
\hline- & Unclass. & A. J. IIndsay & $9-14-60$ & $\begin{array}{l}\text { Status Report - Flow } \\
\text { Monitor Prototype, } \\
\text { DI-1069. }\end{array}$ \\
\hline- & Unclass. & $\begin{array}{l}\text { Instrument } \\
\text { Development } \\
\text { Operation }\end{array}$ & $9-12-60$ & $\begin{array}{l}\text { Report on Analysis of } \\
\text { Flow Monitoring Proposal } \\
\text { Submitted on HWS- } 6507 \text {, } \\
\text { AEC Request } 5921-1160 \\
(7-27-60) \text {. }\end{array}$ \\
\hline $\begin{array}{c}\text { HW- } 66823 \\
R D\end{array}$ & Secret & $\begin{array}{l}\text { E. C. Wood } \\
\text { E. R. Astley } \\
\text { J. B. Brown } \\
\text { L. W. Lang }\end{array}$ & $9-17-60$ & $\begin{array}{l}\text { Major Overboring of } \\
\text { Reactors. }\end{array}$ \\
\hline HW-64676 & Uncless. & R. J. Mollerus & $9-19-60$ & $\begin{array}{l}\text { H Area Trip-out Incident } \\
\text { of 3-11-60, Potential } \\
\text { Ground Faliures. }\end{array}$ \\
\hline $\mathrm{HW}-57036$ & Uncless. & G. E. Wade & $8-31-60$ & $\begin{array}{l}\text { 105-N Design Criteria - } \\
\text { Flssion Product } \\
\text { Confinement System. }\end{array}$ \\
\hline $\mathrm{EW}-65656$ & Unclass. & M. H. Russ & $9-21-60$ & $\begin{array}{l}\text { Heat DIssipation } \\
\text { System Project } \\
\text { Representative } \\
\text { Minutes No. } 59 .\end{array}$ \\
\hline $\mathrm{HW}-65657$ & Unclass. & M. H. Russ & $9-23-60$ & $\begin{array}{l}\text { Heat Dissipation } \\
\text { System Project } \\
\text { Representat1ve } \\
\text { Minutes No. } 60 .\end{array}$ \\
\hline$H W-66716$ & Unclass. & R. B. W1IIson & $8-31-60$ & $\begin{array}{l}\text { Project CAI- } 816 \\
\text { Monthly Design Test } \\
\text { and Development } \\
\text { Status Report for } \\
\text { August. }\end{array}$ \\
\hline $\mathrm{HW}-66637$ & Uncless. & D. D. Stepnewsk1 & $8-30-60$ & $\begin{array}{l}\text { Trip Report - A. D. } \\
\text { Little and GEL. }\end{array}$ \\
\hline EW-66656 & Cone. & F. J. Mollerus & $9-15-60$ & $\begin{array}{l}\text { Preliminary Report - } \\
\text { NPR Post Scram Primary } \\
\text { Coolant Thermal Con- } \\
\text { traction. }\end{array}$ \\
\hline HW- 66651 & Conf. & J. Muraoka & $8-31-60$ & $\begin{array}{l}\text { NPR Process Tube Flow } \\
\text { Distribution During } \\
\text { Emergency Coolant. }\end{array}$ \\
\hline
\end{tabular}




\begin{tabular}{|c|c|c|c|c|}
\hline Number & Closs'D. & Autbor & Date & Title \\
\hline$H W-66697$ & Unclass. & G. T. Haugland & $9-6-60$ & $\begin{array}{l}\text { NPR Thermal Shleld Boron } \\
\text { Steel - Trip Report. }\end{array}$ \\
\hline$E W-66840$ & Unclass. & W. J. Love & $9-23-60$ & $\begin{array}{l}\text { Reactor Steam Release } \\
\text { W1thin the Core. }\end{array}$ \\
\hline & Unclass. & W. J. Love & $9-20-60$ & $\begin{array}{l}\text { Trlp Report - G.I. Reactor } \\
\text { Safeguards Counc1l Meetine }\end{array}$ \\
\hline
\end{tabular}

\section{TRIPS}

Name

J. W. Nageley

D. F. Watson

D. F. Watson

C. E. Jones

A. McDonald

H. A. Kramer

H. A. Kramer

J. H. Fastabend
F1rm \& Iocation

Westinghouse Blectric Willamette Iron Co., Portland, Oregon
Date

$9-2-60$
B. E. Bovay, Jr. Spokane, Weshington

$9-1-60$

$9-26-60$

Frelghtliner Corp.

Portland, Oregon

$9-9-60$

Air Mac, Inc.

Yaktma, Washington

$9-13-60$

Westinghouse Corp. Portland, Oregon

Grand Coulee Dam Grand Coulee, Wash.

9-2- \&

$9-26-60$

Priest Raplds Dam Prlest Rap1ds, Wash.

$9-1,12$

\& $19 / 60$

Machine Tool Exposition \& Production Mngineering Show, Chlcago, Illinols
9-13-60

thru

9-17-60

\section{Purpose}

Review the motor rewinding contract which is pert of the work included in CGI-883, Increased Process Water Flow, 100-K Area.

Discuss CGI-844 design.

Discuss trailer suspension systems for CGI-791.

Inspect straddle lift traller and discuss shock absorbing problems.

Assist Project EngineerIng on inspection of a re-wound Westinghouse motor.

Measure thermocline.

Calibrate the river flow and temperature telemeter.

To discuss NPR tooling. 
Name

J. H. Festabend

C. A. Munro

R. L. Jeffery

E. A. Wegener

E. C. Frantz

G. L. Erickson
F1rm \& Location

Hydraulic \& A1r Equ1pment Co., Iron Fireman Manufacturing Co., Ingersoll-Rand $\mathrm{Co}$, and Omark Industrles. All of Portland, Oregon.

Un1on Machine Corp., Seattle, Wash., \& Nord1ck Manufacturing Co., Kent, Wash.

Amer1can Manufacturing Co., Tacoma, Wash.

Machlne Tool Exposition \& Lovejoy Flexible Coupling Co., In ChIcago, III.; Great Lakes Carbon Co., in Morgantown, N. Car.; Spear Carbon Co., In Nlagara Falls, New York; Nat1onal Carbon Co., in Cleveland, Oh1o.

Norfin, Inc., Seattle, Washington

$9-29-60$ and $9-30-60$

San Diego Sclentific San Dlego, California;

9-11-60 thru Daystrom, LaJolla, Cal1f.; 9-17-60 Englneered Electron1cs, Santa Ana, California; Walkirt Company, Inglewood, Californta; Anadex Instruments, Van Nuys, California; Breck Electronics, Monterey Park, California; Philco, Palo Alto, Cal1f.; Hydro-Aire, Burbank, Calif.; Network Electronlcs; Van Nuys, California; Electronic Components, Van Nuys, California; Sierra Electronics, Menlo Park, Callfornia;
Date Purpose

9-13-60 To alscuss NPR tooling thru

9-17-60

$9-19-60$ thru

9-20-60

$9-23-60$

To discuss modification of a plece of equipment.

$9-13-60$ To discuss universal thru 9-23-60 coupling needs.
To review fabrication of flapper valves.

To evaluate breadboard approaches for differential input alarm modules for fuel rupture monitoring and manufacturers' capabilities with respect to these modules.

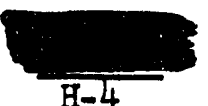


Name

J. E. Kaveck1s

J. E. Kaveckis

J. E. Kaveckis

J. E. Kaveckts

J. E. St1ce

D. C. Keck

C. D. Shadinger

C. E. Love

F. D. Collins

E. W. W1Ison

M. E. Russ
Fyrm \& Locetion

Shockley Trans1stor, Palo Alto, California; Advanced Technology Laborator1es, Mountaln V1ew, Callfornia.

Monitor Systems, Ft. Washington, Penn. Philadelphia, Penn.

Panel11t, Inc., Skokie, Illinols

$9-19-60$

9-15-60

and

$9-16-60$

$9-16-60$
Partlcipate in sub- committee meeting.

Review Panelilt program and status on two channel electronic flow monitor prototype.
General Controls Skok1e, Illino1s; Waterman Baglneerling Co., Bvanston, Illino1s; Fluid Power Accessorles, Glenview, Illino1s;
W. A. Kates Company, Deerfield, IIlinols.
Todd Shtpbuilding co., Seattle, Washington
$9-8-60$ and 9-9-60

9-19-60 thru 9-21-60

Discuss plow regulator requirements for fuel rupture monltoring.

Review status of CGI-802 scanner.
ASA-N6-5 Subcommittee,

$9-15-60$

Heath Manufactur
Kent, Washington

National Carbon Co. Clarkesburg, West Virginia Allegheny-Ludlum Steel P1ttsburgh, Pennsylvenia Wolverlne Tube Co., Allen Park, M1chigan

Star Machinery Co., Seattle, Washington

Burns and Roe, Inc. Hempstead, N. Y.
$9-7-60$

$9-8-60$

$9-9-60$

$9-19-60$

$9-12-60$

thru

9-16-60
Discuss requirements of the 105 Bullding elevators.

Check operation of borescope examination stand.

Review graphite production. Review zirconium tube production. Review zirconium tube production.

Review repalr work on graphlte fabrication equipment.

Consult on heat dissipation plant scope and design preparation. 


\section{Name}

R. A. Rohrbacher

J. F. Nesb1tt

G. T. Haugland

E. G. Johnson

W. J. Morris

R. B. Willson

W. M. Harty

W. J. Love

W. J. Dowls

E. M. Kratz

W. M. Harty
F1rm \& Location

Burns and Roe, Inc.

Bempstead, N. Y.

Wrederic B. Stevens, Inc. Detro1t, M1chlgan

Crucible Steel

P1ttsburgh, Pennsylvania A. M. Byers Company P1ttsburgh, Pennsylvanda Jones and Laughlin Steel P1ttsburgh, Pennsylvania Kalser Engineers P1ttsburgh, Pennsylvanta

C. H. Robins, General Electric Company, San Jose, Californta

\section{Chandler-Evans Corp. Hartford, Connecticut Atwood \& Morrill Salem, Massachusetts Mason-Nellan Norwood, Massachusetts Crane Company Chlcago, Illinois}

Argonne National Lab. Chlcago, Illinois

Burns and Roe, Inc. Hempstead, N. Y.
Date

$9-26-60$ thru

$9-30-60$

9-22-60, thru

$9-26-60$

$8-26-60$

thru

9-3-60

9-28-60

thru

$9-30-60$

$9-12-60$

$9-13-60$

$9-14-60$

$9-15-60$

$9-7-60$

and

9-8-60

$9-8-60$

and

$9-9-60$
Obta1n APED pressure suppression test data and discuss its application to design of NPR emergency dump system.

Review and discuss prototype inlet and diversion valve program and answer questions concerning formal contract language and test procedures.

Attend Reactor Hazards meeting of G.E. Reactor Safeguards Council.

Discussed the cases to be studied in the up-dating of the FPC report on the economic fersibility of NPR conversion.

Aerojet-General Azuza, California Barton Company Monterey Park, California
9-19-60 Technical discussions on engineering protube flow monitoring. posals on process 
Name

R. W. Benoliel

K. W. Norwood

J. B. Brown

R. E. Trumble

O. H. Greager

W. R. Conley

B. C. Bennett F. W. VanWormer

C. T. Hayner

J. W. Green

T. W. Eauff

R. M. Smithers
Firm \& Iocats un

Swartwout Company

Manchester, New Hampshire

Stromberg-Carlson

Rochester, New York

Avien Company

Woods1de, New York

Natlonal Carbon Co. Clarksburg, W. Va.

\author{
Chicago, III. \\ Chilcago, IIl. \\ Chicago, III. \\ Ch1cago, III. \\ Weshington, D.C.
}

Burns \& Roe

Hempstead, N.Y.

General Dymamics Corp. General Atomic DIv. San Dlego, Calif.

Schenectady, N. Y.

New York, Boston \& Chicago

Cincinnat1, Ohio

Dresden Station Joliet, III.

General 피ectr1c Co. Schenectady \& Waterford N. $Y$.

R. D. Nederhood New York City
Date Purpose

$9-22-60$

$9-23-60$

$9-24-60$ DECLASSFFED

9-6-60

thru

$9-8-60$

Observe NPR graphite

manufacture.

9-5-9 '60 Attend GMRSC Mtg.

9-6-10 60 Attend GHRSC Mtg.

9-6-10 60 Attend GERSC Mtg.

9-6-60 Attend GBRSC Mtg. Attend Advisory Committee Mtg. on Blology and Medicine

9-11 60 D1scuss NPR design thru

9-16-60

$9-21-60$

Discuss-MGCR irradiation

thru in the DR-1 Ioop

$9-24-60$

$9-26-60$

Attend Indirect Labor

thru

10-14-60

Meesurement Instructors

class.

9-26-60

thru

Attend Instrument Society of Amer1ca meeting and

10-2-60 visit instrument vendors.
$9-26-60$
thru
9-28-60

Participated in a manufacturing training program district staff meet1ng.

$9-29-60$

Discuss reactor operator training.

$9-6-60$

Discussion of recent developments in maintenance organization structure and performance measurement.

$9-24-60$ thru $10-2-60$

Attended the Instrument Automation Conference. 


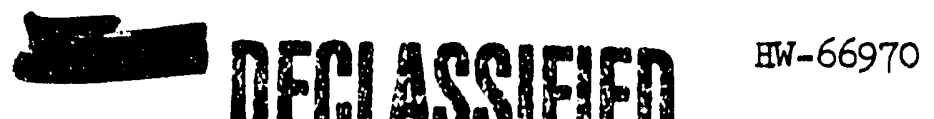 VISITORS}

Name

Guy R. Coe

RIchard C. Pugh

D. L. Snellman

B. A. Pearson

W. A. Kates

J. C. Fryer

Harry E. W1lson

D. W. Letby

Dr. K. Garl1d

W. W. Barton

R. Shustrin

R. Pugh

G. M. Roe
F1rm \& Location

Vickers, Inc.,

Seattle, Washington

E. I. duPont de Nemours

W1lmington, Delaware

Norf1n, Inc.,

Seattle, Washington

Norf1n, Inc.,

Seatt?e, Washington

W. A. Kates Company

Deerfleld, IIllnois

Fryer and Company

Portland, Oregon

Wilson \& Sprow

Spokane, Washington

General Engineerting Lab.

General Electric Co.

Schenectady, New York

UnIversity of Weshington Seattle, Washington

4VF Atomics

Greenw1ch, Connect1cut

duPont Co.

Wilmington, Del.

G. E. Research Lab.

Schenectady, N. Y.
Date

$9-7-60$

$9-7-60$

$9-27-60$

$9-28-60$

$9-14-60$

thru

9-16-60

9-14-60

thru

9-16-60

$9-22-60$

$9-16-60$

$9-12-60$ and

$9-13-60$

$9-26-60$ and

$9-27-60$

$9-7-60$

and

9-8-60

9-13-60

thru

9-15-60
Purpose

To discuss hydraulic power units and controls with J. $H$. Fastabend.

To discuss coextruded zircaloy to stainless steel jolnts.

To discuss Contract DDR-109 w1th C. A. Munro.

To discuss Contract DDR-109 w1th C. A. Munro.

Consultation of flow regulator prototypes.

Consultation of flow regulator prototypes

To discuss mailing of parts.

Review work on NPR Primary Loop Systems Analysis Program.

Discuss problems in two-phase flow and translent heat transfer.

Discuss the mechanlcal, electrical, control and cost aspects of underwater fuel handling system.

Discuss fucl element problems.

Discl:ss optimization; consultation on reactor control problems. 
Name

E. H. WIIIIs

Nuclear Metals, Inc.

Concord, Mass.

W. H. Coleman

Fort Wayne, Indiana
Date

$9-21-60$

and

$9-22-60$

9-19-60

thru

9-23-60
Purpose

D1scuss NPR fuel elements.

Consultation on Manufacturing Training program. 

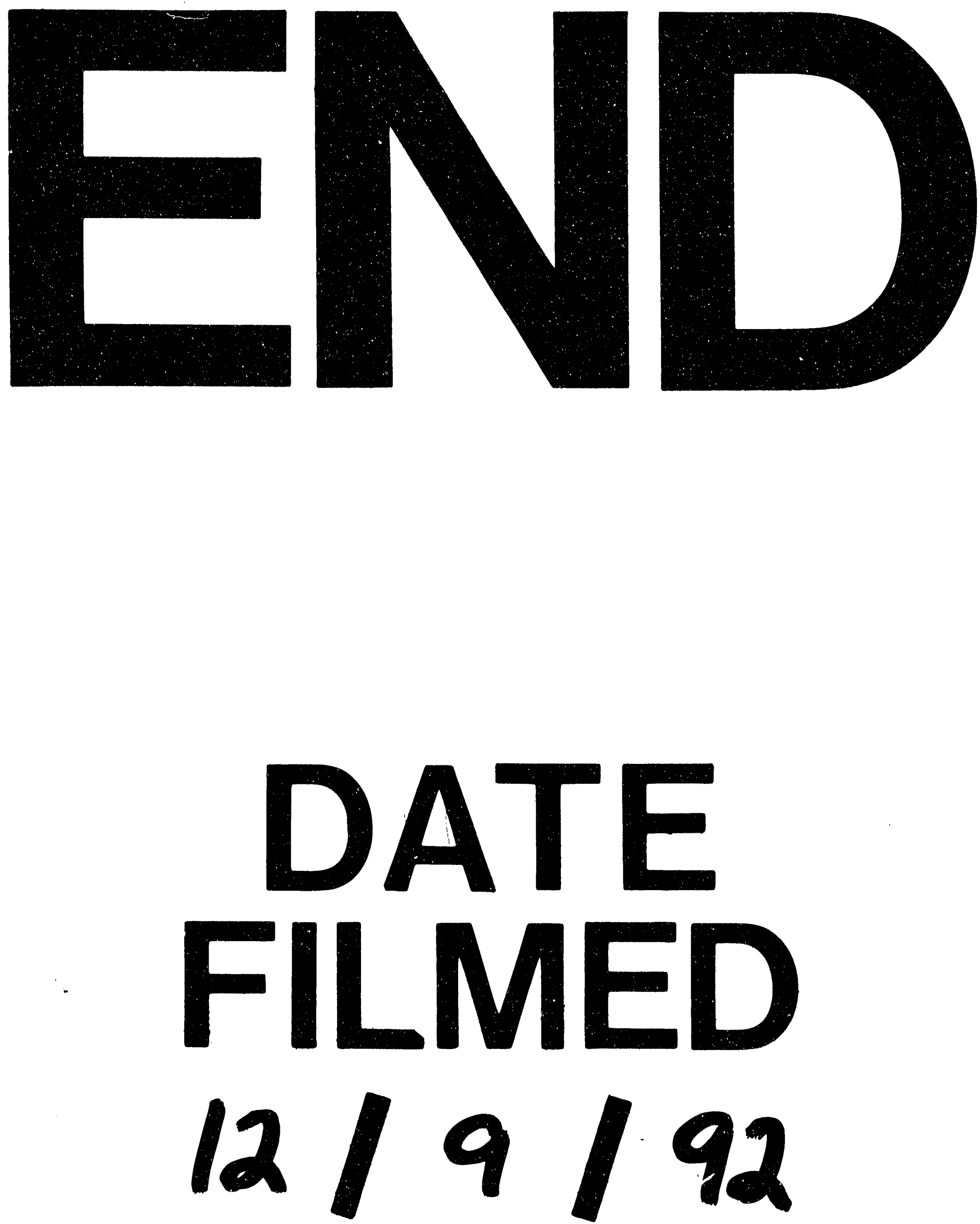
